\title{
On-the-job learning and earnings: Comparative evidence from Morocco and Senegal ${ }^{\#}$
}

\author{
Christophe J. Nordman * $\quad$ François-Charles Wolff ${ }^{* *}$
}

July 2009

\begin{abstract}
In this paper, we consider a model of on-the-job learning where workers learn informally by watching and imitating colleagues. We estimate the rate of knowledge diffusion inside the firm using two matched worker-firm data sets from Morocco and Senegal. We rely on non-linear least squares to estimate the structural parameters of the informal learning model and account for firm heterogeneity using firm factors derived from a principal component analysis. We find that the rate of knowledge diffusion is around 7 percent in Morocco and Senegal, but part of the learning-by-watching returns stems from firm heterogeneity. Informal training significantly affects the shape of returns to tenure in these two countries. Finally, we estimate an extended model with both learning-by-watching and learning-by-doing and find significant benefits from imitating colleagues in Morocco.
\end{abstract}

Keywords: Earnings functions, informal training, learning-by-watching, learning-by-doing, returns to tenure, Morocco, Senegal

JEL Classification: J24, J31, O12

\footnotetext{
\# We gratefully acknowledge valuable comments from Francis Teal and participants at the IZA/World Bank Conference 2008 in Rabat on a first draft of this paper, which has circulated with the title "On-the-job learning and earnings in Benin, Morocco and Senegal", and from participants at the 2009 Conference of the GDRI DREEM in Istanbul. Any remaining errors are ours.

* Corresponding author. IRD, DIAL, 4 rue d'Enghien, 75010 Paris, France. E-mail: nordman@dial.prd.fr

*** LEMNA, Université de Nantes, France; CNAV and INED, Paris, France.

E-mail: wolff@sc-eco.univ-nantes.fr Homepage: http://www.sc-eco.univ-nantes.fr/ fcwolff
} 


\section{Introduction}

Within the academic literature in sociology, there has been a growing interest in workplaces as learning environments and the importance of on-the-job learning in skill formation processes (Garrick, 1998, Boud and Garrick, 1999). In particular, many workplace learning processes are variously described as 'informal' or 'nonformal' (Billett, 2001, Colley et alii, 2003, Hayward and James, 2004). The perceived importance of informal processes in workplace learning is captured by Coffield's image of the learning iceberg (2000, p. 1): "If all learning were to be represented by an iceberg, then the section above the surface of the water would be sufficient to cover formal learning, but the submerged two thirds of the structure would be needed to convey the much greater importance of informal learning".

It is important to appreciate that interest in workplace learning, through both formal and informal processes, is still a relatively recent phenomenon and that evidence about effective practices is still relatively scarce (Battu et alii, 2003). Research on workplace learning in economics is still in late infancy at best, albeit Mincer (1989) was claiming years ago that informal training may constitute the essential part of training provided by firms. If workplace learning, and in particular informal training, is as important in developing vocational knowledge and skills as research is beginning to suggest, then it is also important to understand the ways in which (and of course the extent to which) skill formation resulting from situated learning affects workers' productivity and wages.

While the benefits of investments in human capital are clearly established in the economic profession, the accurate calculation of rates of return to informal training remains complex. One reason is that the usual on-the-job training variables are often affected by measurement errors. Some authors have shown that these errors are likely to bias the estimates of the rates of return to training (Barron et alii, 1997, Loewenstein and Spletzer, 1999, Frazis and Loewenstein, 2005). Moreover, for reasons that are inherent in the very nature of informal training, the few direct measures of informal training available today in data sets are even more imperfect (see the discussion in Barron et alii, 1997, Loewenstein and Spletzer, 1999).

Interestingly, formal training is rather simple to measure as it is clearly identifiable. It is generally provided for a determined duration by a recognised trainer in a precise place. Unfortunately, this is not the case for informal training that appears inextricably part of the employee's productive activity (Brown, 1990). Furthermore, the modeling of a process of informal learning susceptible to be submitted to an empirical test requires the availability of micro data containing information both on workers and on their firm. 
In this contribution, we rely on two matched worker-firm data sets for Morocco and Senegal to study informal training in Africa. The first one is the Firm Analysis and Competitiveness Survey (FACS) conducted in 2000 by the World Bank and the Moroccan Ministry of Trade and Industry, which includes representative data from 859 manufacturing plants. The worker survey collected data from 8375 workers. The second matched data set, made available recently, stems from the Investment Climate Assessment (ICA) survey conducted by the World Bank between 2003 and 2004 in the framework of the Africa Regional Program on Enterprise Development (RPED). The ICA survey for Senegal provides information on 180 firms and more than 1200 employees.

With a method similar to that of Mincer (1974), our approach consists of estimating the returns to informal training using the individual earnings profiles. For that purpose, a structural model of on-the-job learning is developed to conform to the structure of our data. The first presentation of the model appears in the original work of Lévy-Garboua (1994). It has been extended and successively estimated by Chennouf et alii (1997), Nordman (2000), Destré and Nordman (2002), Destré (2003) and Destré et alii (2008). However, the previous estimates suffer from limits that this paper intends to overcome.

The model accounts for on-the-job learning. Workers learn informally on the job by watching others performing their tasks ${ }^{1}$. They may also learn by themselves, i.e. by a sort of learning-by-doing process. In a setting where gross earnings reflect human capital, it is straightforward to show that one can solve a wage recurrence equation after postulating that the knowledge diffusion process within the firm is time-invariant. The human capital of any given worker is expected to increase with tenure, both by learning-by-watching and learningby-oneself. One part of the returns to tenure is hence firm dependent. By taking the logarithms of the earnings equation, we find that the log of gross earnings is the sum of a linear-in-tenure Mincerian earnings functions and a correction function. We estimate the structural parameters of the model using non-linear least squares.

We extend the previous results on the learning model in the following way. First, we structurally take into account a flexible form of the returns to schooling. Indeed, the previous estimated model did not consider the possibility of convex returns to education (Destré et alii, 2008). Yet, constant rates of return to education are more and more challenged in developed and developing countries (Card, 1999), especially in Africa ${ }^{2}$. Second, we introduce controls for the firm's heterogeneity component thanks to the use of a factor analysis of the firms'

\footnotetext{
${ }^{1}$ Employees who are getting informal training may not always be conscious that they are doing so.

${ }^{2}$ See Bigsten et alii (2000), Schultz (2004), Söderbom et alii (2006) and Kuepie et alii (2009).
} 
characteristics and show the impact of these firm factors on the structural parameters of the model. Finally, our estimates are innovative in the context of developing countries. To the best of our knowledge, accurate and comparative assessment of the impact and extent to informal on-the-job training in private firms has never been carried out with matched workerfirm data on Africa.

The issue of informal training is especially important among African countries. Mechanisms for closing the skill gap across categories of workers in Africa have long been articulated in terms of supply-side reforms: improving the educational system so that more young people become educated, and helping existing workers to enhance skills through formal learning, such as classes and accreditation services provided by vocational schools. However, such provision is often believed to be so much subject to supplier capture (as the diversity of vocational schools and diplomas, either private or public suggests) that it does not respond to employer needs.

Quite recently, there is then recognition among policy makers that the demand side of the skills equation also needs attention and that more effort needs to be directed towards the development of the skills of the existing workforce, in addition to improving the educational outcomes of learners in schools, colleges and higher education. This is all the more important given that public vocational education and training systems have generally failed in providing young workers, which are massively found in the informal sector, with the necessary human capital to access stable and decent jobs in the formal sector. Johanson and Adams (2004) show that in Sub-Saharan Africa training by traditional learning (mostly informal) is the most frequent form of training in the informal sector. Traditional learning probably makes a far greater contribution to develop the workers' skills than all the training providers taken together. It is then interesting to gauge the informal training potential of the formal private sector in these economies as well.

Our empirical results suggest that informal learning may be of importance in African firms. We find that the rate of knowledge diffusion is around 7\% in the Moroccan and Senegalese firms of our samples. This means that the workers' tenure which is requested to assimilate half of the firm knowledge is about 10 years. However, part of the learning-bywatching returns stems from firm heterogeneity. Informal training significantly affects the shape of returns to tenure in these African countries. Intuitively, workers will assimilate faster a given proportion of the knowledge of the firm when there is a lot to learn by watching others. We evidence that the learning potential from the most qualified teacher is much lower in Morocco than in Senegal. Finally, we estimate the extended model with both learning-by- 
watching and learning-by-oneself and still evidence significant benefits from imitating colleagues in Morocco.

The remainder of this paper proceeds as follows. In section 2, we present the on-thejob learning model. Section 3 describes the two matched worker-firm surveys together with the information collected from workers and firms respectively for Morocco and Senegal. In Section 4 , we present the econometric strategy to recover the structural parameters of the model. Our results are discussed in Section 5. Section 6 concludes.

\section{A model of learning-by-watching}

While economists mainly focus on formal training, workers may also improve their skills by learning informally, simply while being in their firm and watching other workers performing their tasks. Unlike formal training, this knowledge acquisition process seems not really costly as a firm does not have to provide specific resources for it.

More productive workers may not necessarily devote time to explain other workers how to improve their own productivity. All the training effort remains informal, in the sense that less productive workers are simply expected to watch those who have more knowledge and experience, and then to replicate what they have observed. This imitation process acts as a positive externality whose benefits extend over time. Workers receiving at a given time some informal training from others will be later in a supply position, showing in turn informally to new incumbents how they can enhance their own productivity.

For the presentation, we draw on the model of learning-by-watching first described in Lévy-Garboua (1994) and extended in Destré et alii (2008). Consider a competitive industry where wage rates are equal to the true marginal product of labour, so that earnings reflect pure human capital. Using a discrete-time framework, we denote by $h_{t}$ the amount of human capital for a worker at date $t$. Assume that the worker enters the firm at date 0 , so that $t$ corresponds to tenure. Then, $h_{0}$ is the value of the worker's human capital when starting his activity in the firm. Each individual has presumably accumulated some experience while working in previous firms. Let $x$ be the number of working years spent outside the current firm, so that individual total experience is $x+t$.

In the firm, each worker is supposed to learn from colleagues who have more human capital than him/her. Let $H_{t}$ be the highest level of human capital embodied in colleagues. Importantly, we assume that the firm's knowledge is invariant, meaning that $H_{t}=H$. Owing to the imitation process, a worker's human capital is expected to increase over time by 
learning from others. The following equation describes the dynamics of human capital formation for a worker (see Lévy-Garboua, 1994):

$$
h_{t}-h_{t-1}=\frac{n}{1+n}\left(H-h_{t-1}\right)
$$

where $n$ is the rate of knowledge diffusion inside the firm. We assume that the rate of learning-by-watching is the same for each worker and is time-invariant for the sake of simplicity. For a given value of $n$, human capital will increase faster when the worker has a lot to learn from the most qualified worker. Hence, at the period $t$, the level of human capital is a weighted sum of human capital in $t-1$ and of human capital of the most capable worker:

$$
h_{t}=\frac{n}{1+n} H+\frac{1}{1+n} h_{t-1}
$$

From the recurrence equation (2), we get the following solution for $h_{t}$ :

$$
h_{t}=\left[1-\frac{1}{(1+n)^{t}}\right] H+\frac{1}{(1+n)^{t}} h_{0}
$$

which we can also be expressed as:

$$
h_{t}=h_{0}\left[1+\left(1-\frac{1}{(1+n)^{t}}\right)\left(\frac{H}{h_{0}}-1\right)\right]
$$

As shown in (4), the human capital of a worker is an increasing function of the number of periods spent within the firm $\left(\partial h_{t} / \partial t>0\right)$. Also, we have $\lim _{t \rightarrow \infty} h_{t}=H$. As time goes by, the individual level of human capital converges towards the firm's job-specific knowledge. In this model, the central interest lies in the estimation of the parameter $n$.

In the above formulation, all the job-specific information is learnt from colleagues and the highest level of human capital remains constant. A more realistic framework, considered in Destré et alii (2008) and estimated in Destré and Nordman (2002), is to assume that workers learn both by themselves through their own experience and by watching others ${ }^{3}$. In such setting, the human capital of a worker is both increasing with tenure and it converges towards the firm's job-specific knowledge. However, the latter component is no longer fixed within the firm. Since all workers are expected to learn by themselves, the level of human capital of the most qualified worker is continuously growing.

Now, let $g$ be a measure of the impact of self-learning. The dynamics of human capital formation may be expressed as:

\footnotetext{
${ }^{3}$ By repeating tasks within the firm, a worker is expected to improve his/her own productivity and hence human capital.
} 


$$
h_{t}-h_{t-1}=g h_{t-1}+\frac{n}{1+n}\left(H_{t-1}-h_{t-1}\right)
$$

By definition, there is no learning-by-watching for the most capable worker, meaning that the highest level of human capital will increase inside the firm only owing to self-learning. This implies that $H_{t}=(1+g) H_{t-1}$. Using (5) and after some calculations, we finally deduce the following value for $h_{t}^{4}$ :

$$
h_{t}=(1+g)^{t}\left\{\left(\frac{1+g(1+n)}{(1+g)(1+n)}\right)^{t} h_{0}+\left[1-\left(\frac{1+g(1+n)}{(1+g)(1+n)}\right)^{t}\right] H_{0}\right\}
$$

Clearly, we note that when $g=0$, equation (6) is equivalent to (3), which is the pure learningby-watching case. To end up with this formal presentation, two comments are in order.

First, it is unclear whether the firm's job specific knowledge $H_{t}$ may really be seen as a moving target, increasing at steady state. Imagine a manufacturing firm, with a young worker and a very experienced, older worker. In a context where the technology remains fixed, the latter has certainly nothing more to learn even by him/herself ${ }^{5}$. As a consequence, we estimate first the learning-by-watching model in our empirical analysis and then examine the consequences of self-learning. Second, as clearly shown by (4) and (6), the expression of $h_{t}$ is a non-linear function of both $g$ and $n$. When turning to the data, we rely on non-linear models to recover the structural parameters of informal training.

\section{Data and descriptive statistics}

\subsection{The matched worker-firm data}

We estimate the previous theoretical model in a comparative context with matched employer-employee data collected in Morocco and Senegal. The data for Morocco come from the Firm Analysis and Competitiveness Survey (FACS) conducted in 2000 by the World Bank and the Moroccan Ministry of Trade and Industry. The data for Senegal stem from the Investment Climate Assessment (ICA) survey conducted by the World Bank in 2003-2004 in the framework of the Africa RPED programme ${ }^{6}$.

\footnotetext{
${ }^{4}$ For a more detailed analysis, see the presentation in Destré et alii (2008).

${ }^{5}$ In fact, the worker may even become less productive as time goes by, and could thus be concerned by a decrease in earnings. We rule out this possibility by assuming that there exists some downward wage rigidity.

${ }^{6}$ The Africa Regional Program on Enterprise Development (RPED) is an ongoing research project with the overall purpose of generating business knowledge and policy advice useful to private sector manufacturing development in Sub-Saharan Africa.
} 
These two surveys are based on the notion that the workplace is the microdata unit where labour supply and demand are resolved. In that spirit, the ICA and FACS surveys collected data both on the firm characteristics and on a sample of employees in each workplace. The survey instrument was then a written questionnaire addressed to both employers and employees. The questionnaires are specifically tailored for each country, but they enable cross-country comparisons as they are made of very similar questions.

In Senegal, the firms have been randomly selected among the population of formal establishments and belong to the following ten sectors of production: agro-industry, chemicals and paints, construction materials, food, furniture, metal, paper and publishing, plastics, textile and leather and wood industry. There is no constraint on the size of the firms which were selected in the sample. Conversely, in Morocco, the focus is restricted to formal companies which have at least ten employees. The selected firms are in seven industries: electronics, textiles, garments, food, pharmaceuticals, leather and shoes products, and plastics. Clearly, there is less heterogeneity in the firm sample of Morocco.

Let us describe more precisely the two samples ${ }^{7}$. In Senegal, a sample of 262 manufacturing firms has been surveyed based on a sampling plan made of 1645 formal companies. These firms have been randomly selected using a stratification based on sector, size and localisation and represented $59.6 \%$ of the formal manufacturing firms in 2003 and $68.9 \%$ of its formal permanent jobs. For Morocco, the Moroccan Census of Manufactures was used as the establishment sampling frame, with 1933 formal firms of more than ten employees in the seven sectors mentioned above ${ }^{8}$. The sample includes data from 859 manufacturing plants which are representative of the sampling plan in terms of employment, production and exportation.

The structure of the data allows building up matched worker-firm data sets. Indeed, in each surveyed country, up to ten employees have been randomly sampled in each firm following the idea advocated by Mairesse and Greenan (1999). Note that all the employees of small firms have been interviewed, while the sampling rate decreases with the size of the firms. The number of workers interviewed in Senegal and Morocco are respectively equal to 1645 and 8561.

\footnotetext{
${ }^{7}$ Further details of the surveys and their methodology can be found in World Bank (2005) for Senegal and in World Bank (2002) for Morocco.

${ }^{8}$ A random sample of 1000 establishments and a replacement sample of 500 were drawn by industry, the choice of regions being dictated by the geographical concentration of firms in the selected industries.
} 


\subsection{Descriptive statistics of the workers}

To estimate the structural parameters of the on-the-job learning model, we need several observations of workers in each firm. Recall that we assume that the more capable worker in a given firm takes up the teaching role, and then we estimate the distance to this teacher. We then make the following selections to the initial samples (similar for each country).

First, we restrict the samples to the firms which have information on at least four workers. Second, as our modelling framework is in discrete time, we decide to exclude all the workers having less than one year of tenure in the current firm. In so doing, it may be that we underestimate the rate of knowledge diffusion within the firm, if we assume that the learningby-watching process is very efficient once entering the firm (and there is less to learn from colleagues a couple of months later). However, we also argue that the level of earnings is unlikely to increase just after being hired and before reaching one year of tenure, even if there is a rise in the worker's productivity due to learning from others. Finally, we drop from the sample all the observations with missing values or outliers.

The final samples are described in Table 1. This leaves us with samples comprising 7622 workers and 822 firms in Morocco, and 1284 workers and 180 firms in Senegal. Owing to the large size of its sample, the FACS Moroccan data are expected to be much more informative. More than $75 \%$ of workers are employed in firms with 10 completed individual questionnaires. The same proportion is equal to $31.9 \%$ in Senegal. Meanwhile, the proportion of workers belonging to firms with information on less than 7 respondents is much higher in Senegal than in Morocco (respectively $30.3 \%$ vs. $4.6 \%)^{9}$.

\section{Insert Table 1 here}

The questionnaires of the two surveys allow us to construct identical human capital indicators for the workers in Morocco and Senegal. We compute for each respondent the number of years of completed schooling, the number of years of experience off the current firm and the number of years of tenure in the incumbent firm. All these variables provide good controls for the potential advantage on the labour markets. We further construct a dummy variable which is equal to one when the worker has received formal on-the-job training in the past. Owing to data constraints, this training is off the current job in the case of

\footnotetext{
${ }^{9}$ The distribution of firms by number of employees is characterized by a U-shaped profile in Senegal.
} 
Morocco and in the current firm for Senegal. Finally, we add two demographic variables, i.e. a dummy for gender and a dummy for whether the individual is married or not ${ }^{10}$.

In Table 2, we present some descriptive statistics related to the different covariates introduced into the earnings equations. A first result is that the Moroccan workers are on average the least educated. While the Moroccan employees show on average 8.7 years of education, their Senegalese counterparts exhibit 10.3 years of schooling. This is surprising because Sub-Saharan African countries are often believed to be less endowed in human capital as compared to North African ones. An explanation is that an overwhelming proportion of poorly educated individuals actually work in the informal sector of Senegal (see DIAL, 2007). The latter are thus not in the sample design of the Senegalese ICA survey, as the data we use stem from formal manufacturing firms and their workers. The formal private sector in Senegal, highly selective, might be in fact reserved to the most educated workers. This is probably less true for Morocco where uneducated workers are also found in significant proportion in garment firms for instance.

\section{Insert Table 2 here}

Another explanation may certainly be found in the proportion of females in the two surveys. It is well known that girls face lower educational achievement than boys, especially in developing countries. Interestingly, the proportion of women amounts to $40 \%$ in the case of Morocco, while this proportion is $16 \%$ in the Senegalese case. Nevertheless, note that the specific gender composition of the Moroccan subsample is not so influential when explaining the lower education observed in that country. Indeed, while the mean number of years of schooling is equal to 8.8 among men, it is only slightly lower among women, equal to 8.5 years.

In terms of work experience, the workers of the two samples have the same amount of potential experience off the current firm, which stands at 12.7 years. Tenure in the current firm is on average higher for the Senegalese workers (8.9 versus 7.4 years). Finally, we note that $35 \%$ of the Senegalese workers received formal job training in the incumbent firm. The figure is much lower in Morocco, but it relates to a formal job training episode off the current firm.

To summarize, we evidence quite similar profiles for the workers in the two countries, the two main differences stemming from education and female composition (respectively

\footnotetext{
${ }^{10}$ This variable is approximated in the case of Morocco where the marital status was not collected from the workers. Instead, we use the fact of having declared children. In Morocco like in many African countries, it is reasonable to assume that all individuals who have declared children are (or have been) married because of the social norms in force.
} 
lower and higher in Morocco than in Senegal). As returns to on-the-job learning are expected to depend on both workers' and firms' characteristics, we now further investigate the differences in the composition of the firms.

\subsection{Firm heterogeneity}

For the sake of comparability, it matters to know whether there are any differences in the characteristics of the firms ${ }^{11}$. In Table 3 , we summarize the descriptive statistics of the final samples of selected firms for each country.

\section{Insert Table 3 here}

For Morocco, $40.9 \%$ of the 822 firms are small and medium-sized plants with less than 50 permanent employees. Firms with more than 150 permanent employees represent $23 \%$ of the firm sample. Most of these firms are found in the textile and garment sectors $(60.3 \%)$. More than half of these firms are exporting companies, therefore submitted to strong market competition, especially in the garment sector. However, less than $5 \%$ of the sample of firms can be described as 'multinationals', i.e. with more than $75 \%$ foreign capital. Note that $62 \%$ of the firms have positive profits (hereafter 'profitable' firms).

The Senegalese sample represents well the actual distribution of jobs and firms in the manufacturing sector of Senegal (World Bank, 2005). The firm size is quite similar to that of the Moroccan sample, with $52 \%$ of the 180 plants being small and medium-sized companies. Large-sized firms are also found in relatively fair proportion (21\%). Firms in agro-industry are predominant (34\%), the second most important sector being the industry of paper, closely followed by the textile and leather firms (10\%). There are slightly more foreign owned companies in the Senegalese sample (15\%), while profitable firms are also well represented $(84 \%)$.

To conclude, while the samples of workers look alike in many ways across the three countries, the firm samples are made of different types of firms, especially with regard to the sectors of activity. This justifies taking care of this firm heterogeneity with cautious in the empirical strategy.

\footnotetext{
${ }^{11}$ It also matters for the estimation strategy. If there are very similar firms in the two countries, then one could consider the possibility of pooling all the observations and estimate a single regression. However, this is clearly not the case with the available data sets.
} 


\section{Econometric specification}

We turn to a structural econometric analysis to recover the values of the different parameters of interest. We first consider equation (4) and then show how to add the impact of self-learning into the estimation strategy. By taking the logarithm of $h_{t}$, we get:

$$
\ln h_{t}=\ln h_{0}+\ln \left[1+\left(1-\frac{1}{(1+n)^{t}}\right)\left(\frac{H}{h_{0}}-1\right)\right]
$$

In a setting with only learning-by-watching, we get a human capital earnings function which depends on the human capital of both the worker's initial stock and the most qualified worker. It is also non-linear in both the rate of knowledge diffusion and tenure, so that the appropriate econometric approach is to rely on non-linear least squares (NLSQ).

Suppose that the initial earning (when entering the firm) is not observed. We can then approximate the level $h_{0}$ using a Mincerian earnings function. We introduce into the earnings function both years of education and years of experience outside the firm in a quadratic way. Several studies have indeed shown that returns to education are convex in African countries ${ }^{12}$. We denote by $s, e$ and $t$ respectively years of education, years of experience off the firm and tenure. We express $h_{0}$ as:

$$
h_{0}=\exp \left(\alpha_{0}+\alpha_{1} s+\alpha_{2} s^{2}+\alpha_{3} e+\alpha_{4} e^{2}\right)
$$

since $t=0$ by definition when entering the firm. Assume now that we can perfectly observe the most qualified worker to whom each individual is exposed. Following the same approach, we can rely on a Mincerian earnings function to approximate the level $H$. With $S, E$ and $T$ respectively years of education, years of experience outside the firm and tenure for the most qualified worker and using quadratic profiles for these three covariates, it follows:

$$
H=\exp \left(\alpha_{0}+\alpha_{1} S+\alpha_{2} S^{2}+\alpha_{3} E+\alpha_{4} E^{2}+\alpha_{5} T+\alpha_{6} T^{2}\right)
$$

A difficulty with the data is that we have no information on the most productive worker who may be imitated by each individual. Such observation would require a description of student-teacher interactions within establishments. To overcome this shortcoming, we follow the method of Destré and Nordman (2002) and Destré et alii (2008). There are then two important assumptions. First, as we have matched employer-employee data and observe a random sample of employees from the same firm, we consider the whole set of employees for

\footnotetext{
${ }^{12}$ The assumption of convex returns to human capital seems important. Taking into account a linear form for the returns to education when the "true" profile is convex is likely to lead to an overestimated value of the rate of knowledge diffusion, since workers will benefit less from the rewards of their own personal characteristics when estimating the model.
} 
each firm and suppose that the most qualified worker within the firm is the one with the highest characteristics recorded in the survey ${ }^{13}$. Second, as we are not sure that an individual is really subject to the influence of the most qualified worker (as measured with the data), we account for a distance indicator between the maximum position and the individual situation.

Formally, this means that for an exogenous covariate denoted by $\bar{X}$ for the most productive worker and by $x$ for the selected individual, we suppose that the characteristic of the teacher is such that:

$$
X=\delta_{x} \bar{X}+\left(1-\delta_{x}\right) x
$$

with $\delta_{x}$ a parameter to be estimated $\left(0 \leq \delta_{x} \leq 1\right)$. It measures the relative distance between the individual and the most capable worker within the firm. $\delta_{x}$ takes the value 0 if the individual has no possibility of learning from others and the value 1 if his/her most qualified teacher corresponds effectively to the worker having the biggest $\bar{X}$ of the firm's subsample $^{14}$. This implies that there are three parameters of relative distance to estimate, i.e. $\delta_{s}$, $\delta_{e}$ and $\delta_{t}$. After some calculations, we finally deduce the following non-linear form for the earnings equation under learning-by-watching:

$$
\begin{aligned}
\ln h_{t}= & \ln \left[1+\left(1-\frac{1}{(1+n)^{t}}\right) \exp \left(\begin{array}{l}
\alpha_{1} \delta_{s}(\bar{S}-s)+\alpha_{2} \delta_{s}^{2}(\bar{S}-s)^{2}+2 \alpha_{2} \delta_{s}(\bar{S}-s) s+ \\
\alpha_{3} \delta_{e}(\bar{E}-e)+\alpha_{4} \delta_{e}^{2}(\bar{E}-e)^{2}+2 \alpha_{4} \delta_{e}(\bar{E}-e) e+ \\
\alpha_{5} \delta_{t} \bar{T}+\alpha_{6} \delta_{t}^{2} \bar{T}^{2}
\end{array}\right)\right] \\
& +\alpha_{0}+\alpha_{1} s+\alpha_{2} s^{2}+\alpha_{3} e+\alpha_{4} e^{2}+\beta Z+\varepsilon
\end{aligned}
$$

where $Z$ is a set of control variables, $\beta$ is the corresponding vector of estimates, and $\varepsilon$ is a random perturbation. We estimate equation (11) using non-linear least squares (NLSQ) to get the coefficients of both the parameters and the explanatory variables. Let us briefly discuss identification issues. Clearly, the parameters $\alpha_{0}, \alpha_{1}, \alpha_{2}, \alpha_{3}, \alpha_{4}, \delta_{s}$ and $\delta_{e}$ are identified

\footnotetext{
${ }^{13}$ In that sense, this means that we tend to underestimate the rate of learning-by-watching. Indeed, there may be even more productive workers within the firms, who have not been interviewed during the survey process.

${ }^{14}$ Implicitly, the distance method makes the assumption that any firm includes several knowledge pyramids and that workers can only acquire the knowledge of their work group. Alternatively, Chennouf et alii (1997) made use of firm average human capital variables corrected by a variation index of either education or tenure inside the firm. Nordman (2000) and Destré and Nordman (2002), who applied both methods on the same dataset, show that the alternative techniques provide a negligible difference in the estimation of the parameters of interest. However, the distance indicator seems to be more accurate because the relative knowledge between the "teacher" and the new entrant is then not diluted among mean variables. Ideally, of course, one would like to consider externalities within each occupation, which seems far beyond the possibilities of most available matched employer-employee data on Africa.
} 
according to the data. However, since we have only two estimates for $\alpha_{5} \delta_{t}$ and $\alpha_{6} \delta_{t}^{2}$, this implies that we cannot recover the individual values of the three coefficients $\alpha_{5}, \alpha_{6}$ and $\delta_{t}$.

A very similar strategy is used to estimate the model with both self-learning and learning-by-watching. There is now an additional parameter to estimate, i.e. $g$. From (6), we can express $\ln h_{t}$ as a function of $\ln h_{0}, \ln (1+g)^{t}$ and a third term, more complex, which depends on the ratio $H_{0} / h_{0}, n$ and $g$. The term $H_{0}$ is defined as in (9). Then, using (8) and (10), we obtain a non-linear form which is very similar to (11), except that the log earnings equation is now a function of an additional term $\ln (1+g)^{t}$ and that both $n$ and $g$ affect the exponential expression corresponding to $H_{0} / h_{0}$. If $g$ is small, the extended model of on-thejob learning can then be expressed as:

$$
\begin{aligned}
\ln h_{t}= & g t+\ln \left[1+\left(1-\left(\frac{1+g(1+n)}{(1+g)(1+n)}\right)^{t}\right) \exp \left(\begin{array}{l}
\alpha_{1} \delta_{s}(\bar{S}-s)+\alpha_{2} \delta_{s}^{2}(\bar{S}-s)^{2}+2 \alpha_{2} \delta_{s}(\bar{S}-s) s+ \\
\alpha_{3} \delta_{e}(\bar{E}-e)+\alpha_{4} \delta_{e}^{2}(\bar{E}-e)^{2}+2 \alpha_{4} \delta_{e}(\bar{E}-e) e+ \\
\alpha_{5} \delta_{t} \bar{T}+\alpha_{6} \delta_{t}^{2} \bar{T}^{2}
\end{array}\right)\right] \\
& +\alpha_{0}+\alpha_{1} s+\alpha_{2} s^{2}+\alpha_{3} e+\alpha_{4} e^{2}+\beta Z+\varepsilon
\end{aligned}
$$

Let us observe that if $n$ equals zero, meaning there is no possibility of learning by watching others inside the firm, specification (12) reduces to a simple linear-in-tenure Mincerian earnings function with the parameter $g$ reflecting then a 'gross' effect of tenure on wages (including informal learning effects on wages but admittedly also other aspects of this relationship). One may then interpret specification (12) as a generalisation of the Mincerian model, including a sum of a linear-in-tenure earnings function and a correction factor considering what firms have to offer to their employees in terms of learning ${ }^{15}$.

While the estimation of both non-linear models is quite straightforward using NLSQ, a difficulty stems from the fact that we cannot model unobserved individual heterogeneity as the three data sets are cross-sectional. However, owing to the importance of the work environment in which workers are placed, which is more or less favourable to learning by watching other colleagues, it seems important to control for firm heterogeneity. In theory, firm heterogeneity could be handled in our setting since we have information on several workers per firm.

\footnotetext{
15 The Mincerian model actually offers an accurate description of gross earnings for new entrants, i.e. for $t=0$, and in two other specific circumstances: i) if firms offer no extra knowledge to their employees; and ii) if the rate of knowledge diffusion within firms approaches zero. Both assumptions are clearly unrealistic, but the Mincerian earnings function stands as a first-order approximation insofar as each firm can only make a small contribution to an individual's stock of human capital.
} 
However, the problem is complex when estimating (11) since the extended earnings equations are intrinsically highly non linear. Thus, we cannot control for firm heterogeneity using firm fixed effects. A possibility would be simply to add dummy variables for each firm, but the large number of firms in our data clearly rules out the possibility of using this method. Another strategy to temper the effects of firm heterogeneity consists in adding a large number of control variables to our regressions. In this paper, we rely on an alternative strategy to control for unobserved firm heterogeneity which is likely to bias the estimated coefficients and rely on a factor analysis following Muller and Nordman (2004) and Jellal et alii (2008). We proceed in the following way.

We summarize the main statistical information on the firms' characteristics using first a multivariate analysis and then introduce the computed principal components (factors) into the earnings functions deriving from this analysis. Using factors may be seen as a further step with respect to those studies which have added mean firm variables into earnings functions, individual characteristics being controlled for. With respect to firm fixed effects, the factors are expected to pick up the impact of more qualitative characteristics of the firms. Specifically, we use a principal component analysis (PCA) to summarize the information about the surveyed enterprises ${ }^{16}$. This method is based on the calculation of the inertia axes for a cloud of points that represents the data in table format. As long as the computed factors account for most of the firm heterogeneity, this approach allows us to obtain consistent estimates close to those of the fixed effect estimator. The complete list, definitions and descriptive statistics of the firms' characteristics introduced in the PCA appear in Table 3.

In the case of Morocco, the first ten inertia axes, defined as the estimated factors which are linear components of all the firm's characteristics, concentrate a large proportion of the total variance of the original variables $(63 \%)$. This reflects therefore a fair amount of the relevant information about the firm's characteristics ${ }^{17}$. For Senegal, firm heterogeneity seems to be greater according to very basic descriptive statistics. We thus choose to rely on twelve factors which concentrate $55 \%$ of the total variance of the firm variables.

The correlation coefficients of the firms' characteristics with the factors are used for the interpretation of the computed factors. The ten first factors are closely associated with the firms' sectoral belonging and size (factors 2, 5, 6, 7 and 9 for Morocco, factors 5, 7 and 10 for

\footnotetext{
${ }^{16}$ In a principal component analysis, a set of variables is transformed into orthogonal components, which are linear combinations of the variables and have maximum variance subject to being uncorrelated with one another. Typically, the first few components account for a large proportion of the total variance of the original variables, and hence can be used to summarize the original data.

${ }^{17}$ The detailed results of the two factor analyses (one for each country) are not reported here to save space and are available from the authors upon request.
} 
Senegal), the firms' performances such as their sales, production and profitability (factors 1 and 10 for Morocco, factors 1, 2 and 8 for Senegal), their labour intensity and workforce composition such as whether production, skilled, or executives workers are dominant (factors 3, 6 and 8 for Morocco, 6, 7 and 9 for Senegal) ${ }^{18}$. Hence, the ten factors reflect a wide range of firm characteristics that can mainly be summarised by the sector affiliation, size, performances, and workforce composition.

\section{Econometric results}

\subsection{Basic earnings regressions}

For the sake of comparability, we begin by estimating earnings equations with a set of individual demographic and labour characteristics as control variables. We wonder then whether controlling for firm heterogeneity has an impact or not on our findings. Under the assumption that both $n=0$ and $g=0$, we estimate the earnings functions using simple OLS regressions. The dependent variable is defined as the log of the hourly earnings, which is computed as the ratio of monthly earnings (including additional salaries and premiums) divided by the number of worked hours per month. The corresponding results are in Table 4.

\section{Insert Table 4 here}

In panel $\mathrm{A}$, we describe the estimates obtained without control for firm heterogeneity. Models (1A) and (2A), respectively for Morocco and Senegal, include as regressors education and off the firm work experience along with their squared values, and three dummy variables for being female, married and the receipt of formal job training. The different regressions also include dummy variables related to occupations ${ }^{19}$. For both countries, the results exhibit a convex profile in years of education. The concave profile in off the firm experience is significant in the Moroccan case only.

Interestingly, this finding contradicts much of the comparative studies on the rates of return to education across countries which often use a linear in education specification of the earnings function (see Trostel et alii, 2002). However, constant or decreasing rates are more and more challenged in both developed and developing countries and non-linearities (mostly convexity) in the returns to education have been recently put forward by some studies on Africa (Bigsten et alii, 2000, Schultz, 2004, Söderbom et alii, 2006, Kuepie et alii, 2009).

\footnotetext{
${ }^{18}$ Other important firm characteristics are their risk of lost in the business due to workforce reliability (factors 3 , 4 and 8 for Morocco, 3 and 4 for Senegal) and the firms' general features such as their vocation to export and status of ownership (factors 1 and 4 for Morocco, and factor 5 for Senegal).

${ }^{19}$ As they are not immediately comparable, we do no report the coefficients associated to occupations in Table 4. There are 9 occupational dummies in Morocco and 6 occupational dummies in Senegal.
} 
This result goes against the traditional model of human capital accumulation whereby the marginal return to education is assumed to be constant or even decreasing. When estimating the learning model, we structurally take into account this non-linear profile in education and assess its role on the returns to informal training on earnings.

Concerning the other covariates, we find curiously that the gender dummy is only significant in Morocco. In that country, Nordman and Wolff (2009) have evidenced the presence of a glass ceiling effect using quantile regressions, such that the gender earnings gap is higher at the top of the earnings distribution than at the bottom. The fact that there is no gender difference in Senegal is somewhat surprising, but this result may be due to the low number of female workers in the corresponding sample. Being married has a positive effect in the two countries, and the receipt of formal training (which is treated as exogenous) only really matters in Morocco. Finally, we note that the values of the $\mathrm{R}^{\mathbf{2}}$ in the regressions are reasonably high (around 0.4), but there are less significant explanatory variables in Senegal.

In columns (1B) and (2B), we add in the list of covariates the years of tenure in the firm and rely on a cubic form ${ }^{20}$. Several comments are in order. First, this additional covariate does not really affect the previous estimates, except the marital status whose effect is now much lower. Second, the squared and cubic tenure terms are only significant in Morocco, while they turn to be insignificant in Senegal ${ }^{21}$. Third, we evidence a U-shaped profile for the returns to years of tenure in the current firm without control for firm heterogeneity in Morocco, while the shape is continuously decreasing in Senegal. This result is of interest as it stands in contrast with the standard Mincerian earnings function, which relies on a quadratic profile for years in tenure (the marginal returns to tenure are thus linearly decreasing).

Fourth, we find lower returns to years of tenure in Morocco than in Senegal. The returns to tenure remain rather flat in the former country, equal to $2 \%$ after either 5,10 or 20 years of tenure. These returns amount to $4 \%, 3 \%$ and $2 \%$ in Senegal respectively after 5, 10 and 20 years of tenure ${ }^{22}$. Fifth, we find that it matters to control for the firm heterogeneity. In the two countries, we evidence that the returns to tenure are lower when being calculated with

\footnotetext{
${ }^{20}$ Murphy and Welch (1990) show for the US that more flexible forms of tenure in the earnings function, such as third or fourth order polynomials, better fit to the data.

${ }^{21}$ We have experimented alternative profiles for the effect of years of experience, in particular quadratic and quartic, but these alternative profiles provide a worse fit to the data.

${ }^{22}$ It is interesting to compare our results with those found in Anglophone African countries with similar data sets. For instance, Bigsten et alii (2000) obtain lower rates of return to tenure, though it is difficult to compare their estimates with ours with accuracy as their specifications differ somewhat from ours in that they use a quadratic term in tenure only. From their sample statistics and estimates, however, we can evaluate their rates at $1.8 \%$ for Ghana at the sample mean (after 4 years of tenure), $0.2 \%$ for Kenya (after 7 years), 3.4\% for Zambia (after 6 years) and $0.9 \%$ for Zimbabwe (after 9 years).
} 
either firm fixed effects or firm factors models (see Figure 1). Interestingly, there are no important differences between these two approaches as, in Morocco and to a lesser extent in Senegal, the shape of the returns curve is not really affected by the use of either fixed effects or firm factors ${ }^{23}$. In what follows, we rely on the firm factor strategy when turning to the structural estimation.

\section{Insert Figure 1}

\subsection{Estimation of the learning-by-watching model}

We now turn to the estimation of the structural model of learning-by-watching. For each country, the model is estimated twice using NLSQ, once with individual covariates only and once with inclusion of firm factors in order to pick up the impact of firm unobserved heterogeneity. The corresponding estimates are in Table 5. A first remark is that introducing the possibility of learning-by-watching colleagues does not really affect the coefficients obtained through Mincerian equations for education, experience off the firm, gender or marital status. For instance, being a woman reduces the hourly earnings in Morocco by $7.8 \%$ with the Mincerian specification (without firm controls), and by $7.3 \%$ with the possibility of informal on-the-job training. Interestingly, we still find a convex profile for years of schooling in both countries, at least when firm heterogeneity is controlled for ${ }^{24}$. Conversely, years of experience off the firm always exhibit a concave profile.

Let us focus on the values of the structural parameters of the model. When firm heterogeneity is not controlled for, we find a significant value for $n$ in Morocco and Senegal (at the 1 percent level). This suggests that the learning-by-watching mechanism described in the theoretical section is probably operative in the selected countries. These results are in accordance with the previous findings reported in Chennouf et alii (1997) for Algeria and Canada, Nordman (2000) for Morocco and Mauritius, Destré and Nordman (2002) for Morocco, Tunisia and France and Destré (2003) for France. The rates of knowledge diffusion within firm amount to $6.3 \%$ and $7.6 \%$ respectively in Morocco and Senegal. Our rate of knowledge diffusion for Morocco is then slightly lower than the estimated values found in Nordman (2000) and Destré and Nordman (2002), who have evidenced a rate of diffusion around $15 \%{ }^{25}$.

\footnotetext{
${ }^{23}$ In Senegal, the two profiles are different for a number of years of tenure less than 5 or above 25 .

${ }^{24}$ Without firm factors, the squared term for education is not significant in Senegal.

${ }^{25}$ Note that the sample used for Morocco in Nordman (2000) and Destré and Nordman (2002) is a nonrepresentative sample of workers in only two manufacturing sectors. Interestingly, results reported in Destré
} 
In Figure 2, we show how the diffusion of the firm specific knowledge is sensitive to the parameter $n$. Specifically, we calculate the number of years of tenure which is requested to assimilate a given proportion of the knowledge of the firm. Denoting by $\vartheta$ the share of the firm knowledge, it can easily be shown that the number of years $t$ to assimilate $\vartheta$ is given by $t=-\ln (1-\vartheta) / \ln (1+n)$. Hence, as clearly shown in Figure 2, a worker will get faster a given proportion of the firm knowledge when $n$ is important. For the sake of illustration, suppose that we seek the number of years in tenure to assimilate half of the firm knowledge. We find that $t$ is equal to 11.3 years in Morocco and to 9.5 years in Senegal. The requested years in tenure are respectively equal to 26.3 and 18.9 when $\vartheta=0.8$.

It is of interest to have a look at $\delta_{s}$ and $\delta_{e}$. These parameters measure the relative distance which separates the average worker from the most qualified teacher inside the firm, respectively in terms of years of education and in terms of experience off the firm. We find that the educational distance is much lower in Morocco than in Senegal (respectively 0.069 and 0.430). This explains in part the slightly lower value found for $n$ in Morocco. As the average worker is rather close to his/her most qualified teacher, the potential of learning-bywatching is less important. At the same time, the relative distance in terms of experience off the firm is not significant in Morocco, while it is in Senegal.

Another point of interest relates to the role of firm unobserved heterogeneity. By neglecting the influential role of firm characteristics, it may be that we overestimate the rate of job-specific knowledge diffusion. This would be the case if there are some differences in wage policies among firms related to sectors of activity or to the size of the firm for instance. In models (1B) and (2B) of Table 5, we add in the country-specific regressions a set of firm factors obtained by the PCAs. The main conclusion is that controlling for firm characteristics does significantly reduce the value of the rate of knowledge diffusion. The magnitude of this coefficient is now twice lower both in Morocco and Senegal. It amounts to $3.6 \%$ for the former country and to $3.5 \%$ for the latter, but the parameter is only significant in Morocco (and at the 10 percent level).

\section{Insert Table 5 here}

Finally, we calculate the marginal returns to tenure in the learning-by-watching model. Of course, if workers have the opportunity to learn a lot from colleagues, they are expected to improve quickly their earnings and then the returns to tenure should exhibit a more convex 
profile. Doing as if the time variable $t$ is continuous, we first express equation (11) as $\ln h_{t}=\ln \left[1+\left(1-(1+n)^{-t}\right) A\right]+B, A$ being the exponential term in (11) and $B$ a constant (these two terms are independent of $t$ ). The derivative $\partial \ln h_{t} / \partial t$ is then:

$$
\frac{\partial \ln h_{t}}{\partial t}=\frac{A \ln (1+n)(1+n)^{-t}}{1+\left(1-(1+n)^{-t} A\right)}
$$

which is clearly not linear in $t$ as with Mincerian earnings functions. We describe in Figure 3 the profiles of returns to tenure. For each country, we compare the results from earnings regression with a cubic profile in tenure to those of learning-by-watching models, both without and with firm factors.

\section{Insert Figure 3 here}

Both in Morocco and Senegal, we find that the benefits from learning-by-watching others are essentially reaped by workers during the first ten years of their career. The returns to tenure with the learning-by-watching model are strongly decreasing till about the $15^{\text {th }}$ years of tenure. Owing to the opportunities of imitating others, the returns are more important just after being hired with this model compared with the Mincerian specification. In Morocco, the returns curves of the Mincerian and learning-by-watching model cross at around 20 years in tenure $^{26}$. Finally, in Senegal, the returns to tenure are more convex with the Mincerian specification, so that there are fewer differences with the learning-by-watching model. The possibility of imitating other colleagues conveys again an economic benefit in the first years of the career (at least with no firm factors).

\subsection{Learning from others or learning by oneself?}

In the previous estimations, we have done as if workers were unable to acquire any job knowledge by themselves. We now relax this constraint and estimate the extended model of on-the-job learning given by (12), with both learning from both others and oneself. The model is again estimated using non-linear least squares, respectively without and with firm factors.

For the sake of comparison, we begin by considering a simple model of human capital formation with no possibility of learning-by-watching, i.e. $n=0$. The dynamics of human capital is simply $h_{t+1}=(1+g) h_{t}$, so that we easily deduce $h_{t}=(1+g)^{t} h_{0}$. Taking the

\footnotetext{
${ }^{26} \mathrm{We}$ also note that in Morocco the returns to tenure are slightly lower with the learning-by-watching model with firm factors. As the rate of knowledge diffusion is lower in that case, there are fewer opportunities for workers to learn quickly from others (and then less economic benefits).
} 
logarithm of this expression and assuming that $h_{0}=\exp \left(\alpha_{0}+\alpha_{1} s+\alpha_{2} s^{2}+\alpha_{3} e+\alpha_{4} e^{2}\right)$ as in (8), we estimate the following regression ${ }^{27}$ :

$$
\ln h_{t}=t \ln (1+g)+\alpha_{0}+\alpha_{1} s+\alpha_{2} s^{2}+\alpha_{3} e+\alpha_{4} e^{2}+\beta Z+\varepsilon
$$

It is straightforward to estimate this model with only learning-by-oneself. The various estimates are reported in Table 6. We find very similar values for the parameter $g$ in both countries. It is equal to $1.3 \%$ per year in Morocco and to $1.1 \%$ in Senegal. Results lead to somewhat different findings once accounting for the possibility of imitation within the firm.

\section{Insert Table 6 here}

In the case of Senegal, we find a more important value for $g$ with the extended learning model (columns $2 \mathrm{~B}$ and $2 \mathrm{C}$ ). Indeed, this parameter takes a value of $2.1 \%$ without firm factors and $1.8 \%$ with firm factors. At the same time, we fail to evidence a significant value for the rate of knowledge diffusion. In models (2B) and (2C), the parameter $n$ is still positive and is equal to 0.041 once controlling for firm heterogeneity. A similar result was found with the pure learning-by-watching specification, with an insignificant parameter of 0.035. A last remark, which suggests that there is still something to learn from colleagues despite the insignificant rate of job-specific knowledge diffusion, is that the relative distance separating the average worker from the most qualified worker remains highly significant. In the meantime, the distance is quite low, around 0.16 in presence of firm factors.

In Morocco, introducing the possibility of learning-by-imitation leads to higher returns to learning-by-oneself, just like in the Senegalese case. The parameter $g$ is indeed equal to $3.2 \%$ without firm factors and to $5 \%$ with firm factors. At the same time, while $n$ turns out to be insignificant in model (1B), it appears significant at the 1 percent level and equal to $4 \%$ in model (1C) which controls for firm heterogeneity. Among Moroccan firms, there is thus a real potential benefit of learning from colleagues and this learning-by-watching process also conveys higher benefits to self-learning. Finally, we note that the rate of diffusion of $4 \%$ in the learning-by-oneself and others model (1C) of Table 6 is very close to the value of $3.5 \%$ found in the pure learning-by-watching model (1B) of Table 5.

It is worth comparing our results with those of Destré and Nordman (2002) ${ }^{28}$. For Morocco, these authors have found that the learning-by-oneself process was the only component of informal training that has a significant impact on earnings. Conversely, they

\footnotetext{
${ }^{27}$ Clearly, equation (14) is a restrictive case of (11). It is obtained when the rate of knowledge diffusion is equal to zero, meaning that the characteristics of the most qualified worker are in fact those of the considered worker (there is nothing to learn from others).

${ }^{28}$ Recall that they use small non-representative samples of manufacturing firms in Morocco and Tunisia.
} 
exhibit both a high rate of knowledge diffusion and a significant impact of learning-byoneself (1.9\%) for Tunisian workers. The argument advocated to explain this difference is that the distance with the most educated $(\bar{S}-s)$ in the Tunisian firms is on average higher than in the Moroccan ones, while the number of years of schooling is equivalent in both countries. These statistics may justify the possibilities that learning by imitation is much more important among Tunisian employees.

In our case, however, this does not seem to be a relevant explanation for the divergence of learning effects in the Moroccan and Senegalese cases. While $\bar{S}-s$ amounts on average to 5.5 years for the Moroccan workers, it is 6.7 years for the Senegalese. Besides, the average education is slightly higher for the Senegalese (see subsection 3.2). Similarly, the distance to the most experienced worker is respectively 13.9 versus 14.3 years, again higher for the Senegalese where the benefits of the imitation process are found to be null. Hence, the fact that there are no benefits from learning-by-watching in the Senegalese case should be explained by other factors, beyond the workers' human capital endowments.

A first explanation could lie in strong rigidity in the fixation of wages. Another explanation may refer to the work organisational features within firms, the environment of employees contributing to intensification of the learning-by-watching process. For instance, more compartmentalized firms may leave fewer places to the emergence of peer effects. Unfortunately, we lack relevant information on the firms to know whether Senegalese firms are more partitioned ${ }^{29}$. Finally, the important presence of temporary workers in firms, or firms with high labour turnover, could also explain why the diffusion of knowledge is not efficient. While the ratio of the number of full time temporary workers to the total number of full time permanent employees amounts to $27 \%$ in the Moroccan firms, it is much higher in the Senegalese firms (67\%). The underlying higher turnover may well explain the divergence of knowledge diffusion efficiency between these two countries.

A last comment deals with the interpretation of our results. In particular, can we interpret the estimated parameters of the structural model as pure measures of learning capacities or knowledge externalities? Clearly, given the first-term of the right-hand-side of (12), the estimated parameters of the learning model do not only pick up the tenure effects on earnings since we are able to disentangle the role of $g$ and $n$ when estimating the model.

\footnotetext{
${ }^{29}$ However, indicators of the supervision rates in firms are informative. Note that while the proportion of firms with a share of managers higher than 10 percent of the total employees amounts to $11 \%$ for Morocco, it is much higher for Senegal with 39\%.
} 
Nevertheless, that observed tenure effects on wages reflect pure learning is challenged by alternative interpretations of this relationship.

A first possibility is that there is a positive correlation between recorded tenure and time invariant worker productivity, because high-ability workers get paid well and tend to keep their jobs. Second, job transitions may affect the relationship between tenure and wages if young workers are likely to have higher exit rates, as a result of searching for better paid jobs. The quality of the match, which determines earnings, should be better amongst middleaged workers than for young workers. So, the latter will have short spells of tenure partly because they are young and partly because they switch jobs a lot. It is clear that recorded tenure may be positively correlated with wage for other reasons than pure learning effects. However, since we only have at our disposal a cross-section of workers, we cannot investigate the potential bias introduced by unobserved worker heterogeneity.

\section{Concluding comments}

Using matched worker-firm data from Morocco and Senegal, we have developed and estimated in this paper a model of on-the-job learning which accounts for two forms of informal learning within firms, i.e. learning-by-watching and learning-by-oneself. Our estimates highlight contrasted effects of informal training on earnings. The interest of the model presented consists in the estimation not only of the earnings effects of the self-learning process, but also of the speed of knowledge diffusion within firms.

With a pure learning-by-watching model without controls for firm heterogeneity, we note little difference in the estimated rates of knowledge diffusion for Morocco and Senegal, which are comprised between $6 \%$ and $8 \%$. Slightly less time is hence required for an average Senegalese worker to learn a given proportion of the firm's knowledge. However, controlling for firm characteristics significantly reduces the values of the rate of knowledge diffusion. Also, the rates of return to learning-by-watching are affected by the introduction of the possibility of learning-by-imitation. Both in Morocco and Senegal, the benefits of learningby-oneself are revealed, but the potential benefit of learning from colleagues disappears in the latter country. Moroccan estimates still exhibit significant economic returns to both learningby-watching and self-learning.

From our results, it turns out that the overall return to human capital explaining the remuneration of a given worker involves personal skill characteristics, including individual abilities to learn, but also firms' knowledge characteristics. It is then important to consider these two sources of returns from human capital simultaneously because education policies 
and policies promoting vocational training may affect both worker's human capital and firm's human capital environment. In particular, assessing policies without accounting for educational and knowledge externalities within firms may largely under-estimate the benefits of such policies. 


\section{References}

Barron, J. M., Berger M.C., Black D.A. (1997), "How Well Do We Measure Training?", Journal of Labor Economics, vol. 15, pp. 507-528.

Battu, H., Belfield C., Sloane P. (2003), "Human Capital Spillovers within the Workplace: Evidence for Great Britain", Oxford Bulletin of Economics and Statistics, vol. 65, pp. 575-594.

Bigsten, A., A. Isaksson, M. Soderbom, P. Collier, A. Zeufack, S. Dercon, M. Fafchamps, J.W. Gunning, F. Teal, S. Appleton, B. Gauthier, A. Oduro, R. Oostendorp, C. Patillo (2000), "Rates of Return on Physical and Human Capital in Africa's Manufacturing Sector", Economic Development and Cultural Change, vol. 48, pp. 801-827.

Billett, S. (2001), Learning in the Workplace: Strategies for Effective Practice, Crows Nest, NSW, Allen and Unwin.

Boud, D., Garrick, J. (1999), Understanding Learning at Work, Routledge, London.

Brown, C. (1990), "Empirical Evidence on Private Training", Research in Labor Economics, vol. 11, pp. 97-113.

Card, D. (1999), "The Causal Effect of Education on Earnings", in O. Ashenfelter and D. Card (eds), Handbook of Labor Economics, vol. 3A, pp. 1801-1863, Elsevier, North Holland.

Chennouf, S., Lévy-Garboua L., Montmarquette C. (1997), "Les effets de l'appartenance à un groupe de travail sur les salaires individuels", L’Actualité Économique, 73, pp. 207-232.

Coffield, F. (2000), The Structure Below the Surface: Reassessing the Significance of Informal Learning, in F. Coffield (Ed), The Necessity of Informal Learning, Bristol, Policy Press.

Colley, H., Hodkinson P., Malcolm J. (2003), "Non-formal Learning: Mapping the Conceptual Terrain. A Consultation Report", Lifelong Learning Institute, University of Leeds.

Destré, G. (2003), "Fonctions de gains et diffusion du savoir: une estimation sur données françaises appariées", Economie et Prevision, 158, pp. 89-104

Destré, G., Lévy-Garboua L., Sollogoub M. (2008), "Learning from Experience or Learning from Others? Inferring Informal Training from a Human Capital Earnings Function with Matched Employer-Employee Data", Journal of Socio-Economics, vol. 37(3), pp. 919938.

Destré, G., Nordman C.J. (2002), "The Impacts of Informal Training on Earnings: Evidence from French, Moroccan and Tunisian Employer-Employee Matched Data", SSRN Electronic Library, Human Capital Journal: http://ssrn.com/abstract=314421. Also in L'Actualité Économique, 78(2), pp. 179-205.

DIAL (2007), "Youth and Labour Markets in Africa: A Critical Review of Literature", DIAL Working Paper, DT/2007-02, Paris: DIAL.

Frazis, H., Loewenstein M.A. (2005), "Reexamining the Returns to Training: Functional Form, Magnitude, and Interpretation", The Journal of Human Resources, vol. 40(2), pp. 453-476. 
Garrick, J. (1998), Informal Learning in the Workplace: Unmasking Human Resource Development, Routledge, London.

Hayward, G., James S. (2004), Balancing the Skills Equation: Key Issues and Challenges for Policy and Practice, Hayward G. and James S. (eds), The Policy Press, University of Bristol.

Jellal, M., Nordman C.J., Wolff F.C. (2008), "Evidence on the Glass Ceiling in France using Matched Worker-Firm Data", Applied Economics, vol. 40(24), pp. 3233-3250.

Johanson, R.K., Adams A.V. (2004), Skills Development in Sub-Saharan Africa, Washington, DC: The World Bank.

Kuepie, M., Nordman C.J., Roubaud F. (2009), "Education and Earnings in Urban West Africa", Journal of Comparative Economics, vol. 37(3), forthcoming.

Lévy-Garboua, L. (1994), "Formation sur le tas et rendements de l'expérience : un modèle de diffusion du savoir", Économie et Prévision, n 116, pp. 79-88.

Loewenstein, M. A., Spletzer J. R. (1999), "Formal and Informal Training: Evidence from the NLSY", Working Paper, U.S. Department of Labor.

Mairesse, J., Greenan N. (1999), "Using Employee Level Data in a Firm Level Econometric Study", NBER Working Paper, n 7028, March.

Mincer, J. (1974), Schooling, Experience and Earnings, New-York, Columbia University Press for NBER.

Mincer J. (1989), "Job Training: Costs, Returns and Wage Profiles", NBER Working Paper, $\mathrm{n}^{\circ} 3208$.

Murphy, K. M., Welch F. (1990), "Empirical Age-Earnings Profiles", Journal of Labor Economics, vol. 8, pp. 202-229.

Muller, C., Nordman, C.J. (2004), "Which Human Capital Matters for Rich and Poor's Wages? Evidence from Matched Worker-Firm Data from Tunisia", DIAL Working Paper, DT/2004/09, Paris: DIAL. CREDIT Research Paper, 04/08, University of Nottingham.

Nordman, C.J. (2000), "La formation sur le tas par diffusion du savoir : estimation sur données marocaines et mauriciennes", Revue d'Économie du Développement, vol. 4, pp. 79-103.

Nordman, C.J., Wolff F-C. (2009), "Is there A Glass Ceiling in Morocco? Evidence from Matched Worker-Firm Data", Journal of African Economies, vol. 18(4), pp. 592-633.

Rankin, N., Sandefur J., Teal F. (2006), "Learning and Earnings in Africa: Evidence from Ghana", CSAE Working Paper, University of Oxford.

Rosen, S. (1972), "Learning and Experience in the Labor Market", The Journal of Human Resources, vol. 7(3), pp. 326-342.

Schultz, T. P. (2004), "Evidence of Returns to Schooling in Africa from Household Surveys: Monitoring and Restructuring the Market for Education", Journal of African Economies, vol. 13 , pp. $95-148$.

Sicherman, N. (1990), “The Measurement of On-the-job Training”, Journal of Economic and Social Measurement, vol. 16, pp. 221-230. 
Söderbom, M., Teal F., Wambugu A., Kahyarara G. (2006), "Dynamics of Returns to Education in Kenyan and Tanzanian Manufacturing", Oxford Bulletin of Economics and Statistics, vol. 68, pp. 261-288.

Trostel, P., Walker I., Woolley P. (2002), "Estimates of the Economic Return to Schooling for 28 Countries", Labour Economics, vol. 9, pp. 1-16.

World Bank (2002), Moroccan Manufacturing Sector at the Turn of the Century - Results of the Firm Analysis and Competitiveness Survey (FACS-MOROCCO 2000), The Moroccan Ministry of Industry, Commerce, Energy and Mines and The World Bank, Pilot Investment Climate Assessment Report.

World Bank (2005), Senegal: Une évaluation du climat des investissements, Report No XXSEN, Africa Region, Private Sector and Infrastructure Department, Regional Program on Enterprise Development, March 2005, Washington DC: The World Bank. 
Table 1. Composition of the sample

\begin{tabular}{|l|c|c|c|c|c|c|c|c|}
\hline \multirow{2}{*}{$\begin{array}{l}\text { Number of } \\
\text { employees per }\end{array}$ firm } & \multicolumn{4}{|c|}{ Morocco } & \multicolumn{4}{c|}{ Senegal } \\
\cline { 2 - 9 } & \multicolumn{2}{|c|}{ Workers } & \multicolumn{2}{|c|}{ Firms } & \multicolumn{2}{c|}{ Workers } & \multicolumn{2}{c|}{ Firms } \\
\cline { 2 - 9 } & $\mathrm{N}$ & $\%$ & $\mathrm{~N}$ & $\%$ & $\mathrm{~N}$ & $\%$ & $\mathrm{~N}$ & $\%$ \\
\hline 4 & 40 & 0.5 & 10 & 1.2 & 128 & 10.0 & 32 & 17.8 \\
5 & 130 & 1.7 & 26 & 3.2 & 105 & 8.2 & 21 & 11.7 \\
6 & 180 & 2.4 & 30 & 3.6 & 156 & 12.1 & 26 & 14.4 \\
7 & 224 & 2.9 & 32 & 3.9 & 105 & 8.2 & 15 & 8.3 \\
8 & 320 & 4.2 & 40 & 4.9 & 200 & 15.6 & 25 & 13.9 \\
9 & 1008 & 13.2 & 112 & 13.6 & 180 & 14.0 & 20 & 11.1 \\
10 & 5720 & 75.0 & 572 & 69.6 & 410 & 31.9 & 41 & 22.8 \\
\hline All & 7622 & 100.0 & 822 & 100.0 & 1284 & 100.0 & 180 & 100.0 \\
\hline
\end{tabular}

Sources: ICA Senegal, FACS Morocco.

Table 2. Descriptive statistics of the workers

\begin{tabular}{|l|c|c|}
\hline Variables & Morocco & Senegal \\
\hline Log of hourly earnings & 4.050 & 6.590 \\
Years of education & $(0.616)$ & $(0.885)$ \\
& 8.679 & 10.322 \\
Years of experience off the firm & $(5.428)$ & $(5.661)$ \\
& 12.766 & 12.747 \\
Years of tenure in the firm & $(9.300)$ & $(9.280)$ \\
& 7.435 & 8.981 \\
Female & $(6.305)$ & $(7.870)$ \\
& 0.398 & 0.160 \\
Married & $(0.490)$ & $(0.367)$ \\
& 0.518 & 0.673 \\
Formal training & $(0.500)$ & $(0.469)$ \\
& 0.041 & 0.355 \\
& $(0.199)$ & $(0.479)$ \\
\hline Number of observations & 7622 & 1284 \\
\hline
\end{tabular}

Sources: ICA Senegal, FACS Morocco.

Standard deviations are in parentheses. 
Table 3. Descriptive statistics of the firms

\begin{tabular}{|c|c|c|c|c|c|}
\hline \multirow[t]{2}{*}{ Variable names } & Definitions & \multicolumn{2}{|c|}{ Morocco } & \multicolumn{2}{|c|}{ Senegal } \\
\hline & & mean & s.d. & mean & s.d. \\
\hline secteur1 & Agro industry / Garment for Morocco (1 if yes) & 0.370 & 0.483 & 0.345 & 0.476 \\
\hline secteur2 & Chemicals and related products / Food for Morocco ( 1 if yes) & 0.098 & 0.297 & 0.097 & 0.295 \\
\hline secteur3 & Materials for construction / Textile for Morocco ( 1 if yes) & 0.233 & 0.423 & 0.079 & 0.271 \\
\hline secteur4 & Furniture / Leather for Morocco ( 1 if yes) & 0.078 & 0.268 & 0.034 & 0.182 \\
\hline secteur5 & Metallic products / Electricals for Morocco (1 if yes) & 0.044 & 0.205 & 0.093 & 0.290 \\
\hline secteur6 & Industry of paper and paper products / Chemicals for Morocco ( 1 if yes) & 0.091 & 0.288 & 0.120 & 0.325 \\
\hline secteur7 & Plastics products ( 1 if yes) & 0.086 & 0.280 & 0.078 & 0.268 \\
\hline secteur8 & Textiles and leather (1 if yes) & & & 0.101 & 0.302 \\
\hline secteur9 & Wood ( 1 if yes) & & & 0.046 & 0.209 \\
\hline secteur10 & Other (1 if yes) & & & 0.007 & 0.083 \\
\hline export & Exporting firms ( 1 if yes) & 0.571 & 0.495 & 0.558 & 0.497 \\
\hline pfemme & Share of female employees & 0.570 & 2.233 & 0.103 & 0.124 \\
\hline size & Firm size $(1:<50$ employees, $2: 50<=$ employees $<150,3:$ employees $>=150)$ & 1.820 & 0.778 & 1.688 & 0.796 \\
\hline effecpermplein & Total number of permanent full-time employees & 126.8 & 202.1 & 96.805 & 270.139 \\
\hline qualdominant & Qualified employees being dominant occupation (1 if yes) & 0.328 & 0.470 & 0.203 & 0.403 \\
\hline pqual_mis & Qualified employees being dominant occupation missing ( 1 if yes) & & & 0.038 & 0.192 \\
\hline nonqualdominant & Non qualified employees being dominant occupation ( 1 if yes) & & & 0.285 & 0.452 \\
\hline pnonqual_mis & Share of Unskilled Workers missing (1 if yes) & & & 0.038 & 0.192 \\
\hline pcadredireleve & Share of managers higher than $10 \%$ of the total employees ( 1 if yes) & 0.110 & 0.313 & 0.391 & 0.488 \\
\hline pcadredir_mis & Share of managers missing ( 1 if yes) & & & 0.038 & 0.192 \\
\hline labintensive & Highly labour intensive firms ( 1 if labour costs $>75 \%$ total costs) & 0.023 & 0.151 & 0.003 & 0.056 \\
\hline labintensity & Labour intensity & 0.265 & 0.201 & 0.116 & 0.152 \\
\hline labintensity_mis & Labour intensity missing ( 1 if yes) & & & 0.215 & 0.411 \\
\hline massesal_tot_mis & Total wage costs missing ( 1 if yes) & & & 0.202 & 0.401 \\
\hline etrangere & Firms with more than $75 \%$ foreign owned ( 1 if yes) & 0.042 & 0.200 & 0.151 & 0.358 \\
\hline Klocal & $\%$ of local firm capital & & & 80.861 & 36.119 \\
\hline Klocal_mis & $\%$ of local firm capital missing & & & 0.004 & 0.062 \\
\hline profit & Profitable firms ( 1 if yes) & 0.635 & 0.481 & 0.845 & 0.362 \\
\hline profit_mis & Profitable firms missing ( 1 if yes) & & & 0.643 & 0.479 \\
\hline psalairepiece & Share of piece-rate pay for non qualified employees & 0.005 & 0.061 & & \\
\hline pabsenteism & Share of days lost due to absenteism & 0.024 & 0.058 & & \\
\hline pgreve & Share of days lost due to strike & 0.002 & 0.025 & & \\
\hline pgreve_mis & Share of days lost due to strike missing ( 1 if yes) & 0.229 & 0.420 & & \\
\hline ppertevols & Share of days lost due to theft & 0.003 & 0.012 & & \\
\hline ppertevols $\sim \mathrm{s}$ & Share of days lost due to theft missing (1 if yes) & 0.218 & 0.413 & & \\
\hline daylostgreve & Number of days lost due to strike & & & 0.134 & 1.410 \\
\hline daylostgreve_mis & Number of days lost due to strike missing ( 1 if yes) & & & 0.061 & 0.239 \\
\hline daylostemeutes & Number of days lost due to riots & & & 0.234 & 1.199 \\
\hline daylostemeutes_mis & Number of days lost due to riots missing (1 if yes) & & & 0.061 & 0.239 \\
\hline daylostfamille & Number of days lost due to family events & & & 1.305 & 7.242 \\
\hline daylostfamille_mis & Number of days lost due to family events missing ( 1 if yes) & & & 0.099 & 0.299 \\
\hline valpertevols & Value of losts due to thefts, vandalism or arson & & & 0.529 & 1.600 \\
\hline valpertevols_mis & Value of losts due to thefts, vandalism or arson missing & & & 0.129 & 0.336 \\
\hline formation & Firm provided (on- or off-the-job) formal training ( 1 if yes) & & & 0.393 & 0.489 \\
\hline jourformestot & Number of days of provided formal training & $130.60 *$ & 1992.86 & 18.777 & 66.082 \\
\hline sale & Sales of the firm the year preceding the survey** & $2.5^{\mathrm{E}}+04$ & $5.1^{\mathrm{E}}+04$ & $4.2^{\mathrm{E}}+09$ & $1.4^{\mathrm{E}}+10$ \\
\hline sale_mis & Sales of the firm the year preceding the survey missing & & & 0.090 & 0.286 \\
\hline prod & Value of the production the year preceding the survey** & $2.3 \mathrm{E}+04$ & $4.5^{\mathrm{E}}+04$ & $8.8^{\mathrm{E}}+08$ & $5.0^{\mathrm{E}}+09$ \\
\hline prod_mis & Value of the production the year preceding the survey missing & & & 0.640 & 0.480 \\
\hline psyndic & Share of unionised employees & & & 0.342 & 0.402 \\
\hline psyndic_mis & Share of unionised employees missing & & & 0.048 & 0.214 \\
\hline pnoschool & Share of uneducated workers in permanent employees & & & 0.107 & 0.165 \\
\hline pprimaire & Share of primary school workers in permanent employees & & & 0.256 & 0.257 \\
\hline pcollege & Share of middle school workers in permanent employees & & & 0.180 & 0.195 \\
\hline plycee & Share of high school workers in permanent employees & & & 0.152 & 0.178 \\
\hline puniv & Share of higher educated workers in permanent employees & & & 0.125 & 0.131 \\
\hline propmoins 30 & Share of $<30$ years old workers & & & 0.203 & 0.210 \\
\hline
\end{tabular}




\begin{tabular}{|l|l|r|r|} 
prop30_45 & Share of 30-45 years old workers & 0.493 & 0.255 \\
propplus45 & Share of $>45$ years old workers & 0.212 & 0.213 \\
\hline & Number of observations & 822 & 180
\end{tabular}

Sources: ICA Senegal, FACS Morocco.

*: Number of on-the-job day trainees.

**: in local currencies.

Standard deviations are in parentheses. To avoid dropping firm observations with missing values in the factor analysis, we use the modified zero-order regression method described in Maddala (1977): observations with missing information are set to zero and we include in the analysis a dummy variable for the missing observations.

The factor analysis (PCA) includes the following firm variables:

Morocco: secteur1, secteur2, secteur3, secteur4, secteur5, secteur6, secteur7, export, pfemme, size, psalairepiece, qualdominant, pcadredireleve, labintensive, etrangere, profit, pabsenteism, pgreve, pgreve_mis, ppertevols, ppertevols_mis, jourformestot, sale, prod.

Senegal: secteur1, secteur2, secteur3, secteur4, secteur5, secteur6, secteur7, secteur8, secteur9, secteur10, export, pfemme, size, qualdominant, pqual_mis, nonqualdominant, pnonqual_mis, pcadredireleve, pcadredir_mis, labintensive, labintensity, labintensity_mis, massesal_tot_mis, etrangere, Klocal, Klocal_mis, profit, profit_mis, daylostgreve, daylostgreve_mis, daylostemeutes, daylostemeutes_mis, daylostfamille, daylostfamille_mis, valpertevols, valpertevols_mis, formation, jourformestot, sale, sale_mis, prod, prod_mis, psyndic, psyndic_mis, pnoschool, pprimaire, pcollege, plycee, puniv, propmoins30, prop30_45, propplus45. 
Table 4. Estimates of the log of hourly earnings

A. Without controls of firm heterogeneity

\begin{tabular}{|c|c|c|c|c|}
\hline \multirow[t]{2}{*}{ Variables } & \multicolumn{2}{|c|}{ Morocco } & \multicolumn{2}{|c|}{ Senegal } \\
\hline & (1A) & (1B) & $(2 \mathrm{~A})$ & (2B) \\
\hline Constant & $\begin{array}{c}3.443 * * * \\
(34.55)\end{array}$ & $\begin{array}{c}3.177 * * * \\
(32.37)\end{array}$ & $\begin{array}{c}5.594 * * * \\
(52.73)\end{array}$ & $\begin{array}{c}5.087 * * * \\
(44.16)\end{array}$ \\
\hline Years of education & $\begin{array}{c}-0.018 * * * \\
(4.85)\end{array}$ & $\begin{array}{c}-0.006 * \\
(1.80)\end{array}$ & $\begin{array}{l}0.011 \\
(0.92)\end{array}$ & $\begin{array}{c}0.027 * * \\
(2.39)\end{array}$ \\
\hline Years of education $^{2}(/ 10)$ & $\begin{array}{c}0.026 * * * \\
(11.43)\end{array}$ & $\begin{array}{c}0.026 * * * \\
(11.61)\end{array}$ & $\begin{array}{c}0.014 * * * \\
(2.72)\end{array}$ & $\begin{array}{c}0.017 * * * \\
(3.33)\end{array}$ \\
\hline Years of experience off the firm & $\begin{array}{c}0.005^{* *} \\
(2.51)\end{array}$ & $\begin{array}{c}0.016 * * * \\
(8.27)\end{array}$ & $\begin{array}{l}0.007 \\
(1.15)\end{array}$ & $\begin{array}{c}0.025 * * * \\
(4.08)\end{array}$ \\
\hline Years of experience off the firm ${ }^{2}(/ 10)$ & $\begin{array}{c}-0.002 * * * \\
(3.86)\end{array}$ & $\begin{array}{c}-0.003 * * * \\
(6.38)\end{array}$ & $\begin{array}{r}-0.002 \\
(1.27)\end{array}$ & $\begin{array}{c}-0.004 * * \\
(2.51)\end{array}$ \\
\hline Female & $\begin{array}{c}-0.105 * * * \\
(9.00)\end{array}$ & $\begin{array}{c}-0.078 * * * \\
(6.84)\end{array}$ & $\begin{array}{c}-0.074 \\
(1.21)\end{array}$ & $\begin{array}{c}-0.016 \\
(0.28)\end{array}$ \\
\hline Married & $\begin{array}{c}0.171 * * * \\
(14.12)\end{array}$ & $\begin{array}{c}0.062 * * * \\
(4.79)\end{array}$ & $\begin{array}{c}0.407 * * * \\
(9.45)\end{array}$ & $\begin{array}{c}0.169 * * * \\
\quad(3.65)\end{array}$ \\
\hline Receipt of formal training & $\begin{array}{c}0.260 * * * \\
(9.50)\end{array}$ & $\begin{array}{c}0.263 * * * \\
(9.89)\end{array}$ & $\begin{array}{l}0.086 * \\
(1.86)\end{array}$ & $\begin{array}{l}0.058 \\
(1.30)\end{array}$ \\
\hline Years of tenure in the firm & & $\begin{array}{c}0.034 * * * \\
(7.35)\end{array}$ & & $\begin{array}{c}0.050 * * * \\
(3.16)\end{array}$ \\
\hline Years of tenure in the firm ${ }^{2}(/ 10)$ & & $\begin{array}{c}-0.012 * * * \\
(3.47)\end{array}$ & & $\begin{array}{c}-0.009 \\
(0.83)\end{array}$ \\
\hline Years of tenure in the firm ${ }^{3}(/ 100)$ & & $\begin{array}{c}0.003 * * * \\
(3.53)\end{array}$ & & $\begin{array}{l}0.001 \\
(0.44)\end{array}$ \\
\hline Observations & 7622 & 7622 & 1284 & 1284 \\
\hline R-squared & 0.43 & 0.46 & 0.42 & 0.48 \\
\hline
\end{tabular}

B. With controls of firm heterogeneity

\begin{tabular}{|c|c|c|c|c|}
\hline \multirow[t]{2}{*}{ Variables } & \multicolumn{2}{|c|}{ Morocco } & \multicolumn{2}{|c|}{ Senegal } \\
\hline & (1C) & (1D) & (2C) & (2D) \\
\hline Constant & $\begin{array}{c}3.242 * * * \\
(41.21)\end{array}$ & $\begin{array}{c}3.292 * * * \\
(35.63)\end{array}$ & $\begin{array}{c}5.421 * * * \\
(54.05)\end{array}$ & $5.153 * * *$ \\
\hline Years of education & $\begin{array}{l}-0.002 \\
(0.71)\end{array}$ & $\begin{array}{l}-0.001 \\
(0.26)\end{array}$ & $\begin{array}{l}0.011 \\
(1.12)\end{array}$ & $\begin{array}{c}0.020^{*} \\
(1.89)\end{array}$ \\
\hline Years of education $^{2}(/ 10)$ & $\begin{array}{c}0.018^{* * *} \\
(8.93)\end{array}$ & $\begin{array}{c}0.018 * * * \\
(8.64)\end{array}$ & $\begin{array}{c}0.013 * * * \\
(3.06)\end{array}$ & $\begin{array}{c}0.017 * * * \\
(3.39)\end{array}$ \\
\hline Years of experience off the firm & $\begin{array}{c}0.013 * * * \\
(8.62)\end{array}$ & $\begin{array}{c}0.013 * * * \\
(7.45)\end{array}$ & $\begin{array}{c}0.013 * * \\
(2.54)\end{array}$ & $\begin{array}{c}0.024 * * * \\
(4.16)\end{array}$ \\
\hline Years of experience off the firm ${ }^{2}(/ 10)$ & $\begin{array}{c}-0.002 * * * \\
(5.74)\end{array}$ & $\begin{array}{c}-0.002 * * * \\
(5.38)\end{array}$ & $\begin{array}{l}-0.001 \\
(0.94)\end{array}$ & $\begin{array}{c}-0.004 * * * \\
(2.59)\end{array}$ \\
\hline Female & $\begin{array}{c}-0.066^{* * * *} \\
(6.79)\end{array}$ & $\begin{array}{c}-0.065^{* * * *} \\
(5.89)\end{array}$ & $\begin{array}{l}-0.032 \\
(0.65)\end{array}$ & $\begin{array}{l}0.035 \\
(0.61)\end{array}$ \\
\hline Married & $\begin{array}{c}0.048 * * * \\
(4.64)\end{array}$ & $\begin{array}{c}0.059 * * * \\
(4.85)\end{array}$ & $\begin{array}{c}0.081 * * \\
(2.11)\end{array}$ & $\begin{array}{c}0.171 * * * \\
(3.82)\end{array}$ \\
\hline Receipt of formal training & $\begin{array}{l}0.024 \\
(0.86)\end{array}$ & $\begin{array}{c}0.134 * * * \\
(5.27)\end{array}$ & $\begin{array}{c}0.089 * * \\
(2.30)\end{array}$ & $\begin{array}{l}0.043 \\
(1.00)\end{array}$ \\
\hline Years of tenure in the firm & $\begin{array}{c}0.036 * * * \\
(8.47)\end{array}$ & $\begin{array}{c}0.029 * * * \\
(6.58)\end{array}$ & $\begin{array}{c}0.034 * * \\
(2.31)\end{array}$ & $\begin{array}{c}0.048 * * * \\
(3.10)\end{array}$ \\
\hline Years of tenure in the firm ${ }^{2}(/ 10)$ & $\begin{array}{c}-0.014 * * * \\
(4.58)\end{array}$ & $\begin{array}{c}-0.011 * * * \\
(3.32)\end{array}$ & $\begin{array}{l}-0.003 \\
(0.35)\end{array}$ & $\begin{array}{l}-0.014 \\
(1.31)\end{array}$ \\
\hline Years of tenure in the firm ${ }^{3}(/ 100)$ & $\begin{array}{c}0.002^{* * * *} \\
(3.86)\end{array}$ & $\begin{array}{c}0.002 * * * \\
(3.36)\end{array}$ & $\begin{array}{l}-0.000 \\
(0.23) \\
\end{array}$ & $\begin{array}{l}0.002 \\
(0.91) \\
\end{array}$ \\
\hline Observations & 7622 & 7622 & 1284 & 1284 \\
\hline R-squared & 0.51 & 0.52 & 0.46 & 0.52 \\
\hline
\end{tabular}

Sources: ICA Senegal, FACS Morocco.

Regressions (A) and (B) are OLS, (C) are fixed effects models, and (D) are OLS estimates with firm factors. Absolute value of t statistics are in parentheses, significance levels being respectively equal to $1 \%(* * *), 5 \%$ $(* *)$ and $10 \%(*)$. All regressions also include a set of dummies for occupation. 
Table 5. Structural estimates of the learning-by-watching model

\begin{tabular}{|c|c|c|c|c|}
\hline \multirow[t]{2}{*}{ Variables } & \multicolumn{2}{|c|}{ Morocco } & \multicolumn{2}{|c|}{ Senegal } \\
\hline & $(1 \mathrm{~A})$ & (1B) & $(2 \mathrm{~A})$ & (2B) \\
\hline Constant & $\begin{array}{c}3.260 * * * \\
(33.42)\end{array}$ & $\begin{array}{c}3.365^{* * * *} \\
(36.47)\end{array}$ & $\begin{array}{c}4.854 * * * \\
(39.36)\end{array}$ & $\begin{array}{c}5.216 * * * \\
(45.94)\end{array}$ \\
\hline Years of education & $\begin{array}{c}-0.021 * * * \\
(4.95)\end{array}$ & $\begin{array}{c}-0.008^{*} \\
(1.95)\end{array}$ & $\begin{array}{c}0.065^{* * * *} \\
(7.52)\end{array}$ & $\begin{array}{l}0.004 \\
(0.32)\end{array}$ \\
\hline Years of education $^{2}(/ 10)$ & $\begin{array}{c}0.033 * * * \\
(13.13)\end{array}$ & $\begin{array}{c}0.021 * * * \\
(8.96)\end{array}$ & $\begin{array}{l}0.002 \\
(1.07)\end{array}$ & $\begin{array}{c}0.025^{* * *} \\
(4.14)\end{array}$ \\
\hline Years of experience off the firm & $\begin{array}{c}0.015^{* * *} \\
(7.24)\end{array}$ & $\begin{array}{c}0.011 * * * \\
(5.88)\end{array}$ & $\begin{array}{c}0.029 * * * \\
(4.40)\end{array}$ & $\begin{array}{c}0.030 * * * \\
(4.87)\end{array}$ \\
\hline Years of experience off the firm ${ }^{2}(/ 10)$ & $\begin{array}{c}-0.003 * * * \\
(5.67)\end{array}$ & $\begin{array}{c}-0.002^{* * * *} \\
(4.29)\end{array}$ & $\begin{array}{c}-0.004 * * * \\
(2.89)\end{array}$ & $\begin{array}{c}-0.005^{* * * *} \\
(3.30)\end{array}$ \\
\hline Female & $\begin{array}{c}-0.073 * * * \\
(6.38)\end{array}$ & $\begin{array}{c}-0.064 * * * \\
(5.82)\end{array}$ & $\begin{array}{l}0.009 \\
(0.15)\end{array}$ & $\begin{array}{l}0.056 \\
(1.00)\end{array}$ \\
\hline Married & $\begin{array}{c}0.074 * * * \\
(5.74)\end{array}$ & $\begin{array}{c}0.074 * * * \\
(6.14)\end{array}$ & $\begin{array}{c}0.191 * * * \\
(4.28)\end{array}$ & $\begin{array}{c}0.183 * * * \\
(4.22)\end{array}$ \\
\hline Receipt of formal training & $\begin{array}{c}0.243 * * * \\
(9.13)\end{array}$ & $\begin{array}{c}0.129 * * * \\
(5.06)\end{array}$ & $\begin{array}{l}0.049 \\
(1.13)\end{array}$ & $\begin{array}{l}0.044 \\
(1.05)\end{array}$ \\
\hline$\delta_{s}$ & $\begin{array}{c}0.069 * * * \\
(5.83)\end{array}$ & $\begin{array}{c}0.061 * * * \\
(2.69)\end{array}$ & $\begin{array}{c}0.430 * * * \\
(3.74)\end{array}$ & $\begin{array}{c}0.142^{* * *} * \\
(3.07)\end{array}$ \\
\hline$\delta_{e}$ & $\begin{array}{l}0.026 \\
(1.19)\end{array}$ & $\begin{array}{l}0.001 \\
(0.02)\end{array}$ & $\begin{array}{c}0.150 * * * \\
(2.75)\end{array}$ & $\begin{array}{c}0.120 * * \\
(2.05)\end{array}$ \\
\hline$\alpha_{5} \delta_{t}$ & $\begin{array}{c}0.014 * * * \\
(3.53)\end{array}$ & $\begin{array}{c}0.019 * * \\
(2.42)\end{array}$ & $\begin{array}{c}0.023 * * \\
(2.25)\end{array}$ & $\begin{array}{l}0.025 \\
(1.41)\end{array}$ \\
\hline$\alpha_{6} \delta_{t}^{2}$ & $\begin{array}{l}0.000 \\
(0.51)\end{array}$ & $\begin{array}{l}-0.000 \\
(0.79)\end{array}$ & $\begin{array}{l}-0.000 \\
(0.20)\end{array}$ & $\begin{array}{l}-0.000 \\
(0.70)\end{array}$ \\
\hline$n$ & $\begin{array}{c}0.063^{* * * *} \\
(3.50)\end{array}$ & $\begin{array}{l}0.036^{*} \\
(1.90)\end{array}$ & $\begin{array}{c}0.076^{* * *} * \\
(2.61)\end{array}$ & $\begin{array}{l}0.035 \\
(1.45)\end{array}$ \\
\hline $\begin{array}{l}\text { Observations } \\
\text { R-squared }\end{array}$ & $\begin{array}{l}7622 \\
0.46\end{array}$ & $\begin{array}{l}7622 \\
0.52\end{array}$ & $\begin{array}{l}1284 \\
0.50\end{array}$ & $\begin{array}{l}1284 \\
0.53\end{array}$ \\
\hline
\end{tabular}

Sources: ICA Senegal, FACS Morocco.

Regressions (A) and (B) are estimated using non-linear least squares, models (B) including firm factors. Absolute value of $\mathrm{t}$ statistics are in parentheses, significance levels being respectively equal to $1 \%(* * *), 5 \%$ $(* *)$ and $10 \%(*)$. All regressions also include a set of dummies for occupation. 
Table 6. Structural estimates of the learning by oneself and others model

\begin{tabular}{|c|c|c|c|c|c|c|}
\hline \multirow[t]{2}{*}{ Variables } & \multicolumn{3}{|c|}{ Morocco } & \multicolumn{3}{|c|}{ Senegal } \\
\hline & $(1 \mathrm{~A})$ & $(1 \mathrm{~B})$ & $(1 \mathrm{C})$ & $(2 \mathrm{~A})$ & $(2 \mathrm{~B})$ & $(2 \mathrm{C})$ \\
\hline Constant & $\begin{array}{c}2.324 * * * \\
(25.26)\end{array}$ & $\begin{array}{c}3.187 * * * \\
(32.54)\end{array}$ & $\begin{array}{c}3.298 * * * \\
(35.81)\end{array}$ & $\begin{array}{c}4.200 * * * \\
(45.48)\end{array}$ & $\begin{array}{c}5.028 * * * \\
(46.52)\end{array}$ & $\begin{array}{c}5.190 * * * \\
(51.32)\end{array}$ \\
\hline Years of education & $\begin{array}{l}-0.001 \\
(0.19)\end{array}$ & $\begin{array}{c}-0.008 * * \\
(2.12)\end{array}$ & $\begin{array}{l}-0.004 \\
(1.08)\end{array}$ & $\begin{array}{c}0.033 * * * \\
(3.03)\end{array}$ & $\begin{array}{c}0.028 * \\
(1.94)\end{array}$ & $\begin{array}{l}0.017 \\
(1.22)\end{array}$ \\
\hline Years of education $^{2}(/ 10)$ & $\begin{array}{c}0.018 * * * \\
(8.51)\end{array}$ & $\begin{array}{c}0.027 * * * \\
(11.69)\end{array}$ & $\begin{array}{c}0.020 * * * \\
(9.04)\end{array}$ & $\begin{array}{c}0.015 * * * \\
(3.09)\end{array}$ & $\begin{array}{c}0.021 * * * \\
(3.32)\end{array}$ & $\begin{array}{c}0.024 * * * \\
(3.93)\end{array}$ \\
\hline Years of experience off the firm & $\begin{array}{c}0.013 * * * \\
(7.13)\end{array}$ & $\begin{array}{c}0.015 * * * \\
(7.79)\end{array}$ & $\begin{array}{c}0.014 * * * \\
(7.47)\end{array}$ & $\begin{array}{c}0.028 * * * \\
(4.68)\end{array}$ & $\begin{array}{c}0.037 * * * \\
(5.67)\end{array}$ & $\begin{array}{c}0.032 * * * \\
(5.19)\end{array}$ \\
\hline Years of experience off the firm ${ }^{2}(/ 10)$ & $\begin{array}{c}-0.002 * * * \\
(5.07)\end{array}$ & $\begin{array}{c}-0.003 * * * \\
(6.23)\end{array}$ & $\begin{array}{c}-0.003 * * * \\
(5.59)\end{array}$ & $\begin{array}{c}-0.004 * * * \\
(2.82)\end{array}$ & $\begin{array}{c}-0.006^{* * * *} \\
(3.82)\end{array}$ & $\begin{array}{c}-0.005 * * * \\
(3.31)\end{array}$ \\
\hline Female & $\begin{array}{c}-0.064 * * * \\
(5.82)\end{array}$ & $\begin{array}{c}-0.077 * * * * \\
(6.77)\end{array}$ & $\begin{array}{c}-0.064 * * * \\
(5.81)\end{array}$ & $\begin{array}{c}0.185 * * * \\
(3.63)\end{array}$ & $\begin{array}{c}0.168 * * * \\
(3.24)\end{array}$ & $\begin{array}{c}0.197 * * * \\
(3.93)\end{array}$ \\
\hline Married & $\begin{array}{c}0.063^{* * * *} \\
(5.24)\end{array}$ & $\begin{array}{c}0.061 * * * \\
(4.73)\end{array}$ & $\begin{array}{c}0.061 * * * \\
(4.99)\end{array}$ & $\begin{array}{c}0.187 * * * \\
(4.16)\end{array}$ & $\begin{array}{c}0.171 * * * \\
(3.72)\end{array}$ & $\begin{array}{c}0.170 * * * \\
(3.82)\end{array}$ \\
\hline Receipt of formal training & $\begin{array}{c}0.136 * * * \\
(5.32)\end{array}$ & $\begin{array}{c}0.265 * * * \\
(9.94)\end{array}$ & $\begin{array}{c}0.134 * * * \\
(5.26)\end{array}$ & $\begin{array}{c}0.119 * * * \\
(2.81)\end{array}$ & $\begin{array}{c}0.127 * * * \\
(2.96)\end{array}$ & $\begin{array}{c}0.115^{* * *} \\
(2.74)\end{array}$ \\
\hline$\delta_{s}$ & & $\begin{array}{c}0.376 * * * \\
(4.32)\end{array}$ & $\begin{array}{c}0.228^{* *} \\
(1.98)\end{array}$ & & $\begin{array}{c}0.070 * * * \\
(3.26)\end{array}$ & $\begin{array}{c}0.161 * * \\
(2.40)\end{array}$ \\
\hline$\delta_{e}$ & & $\begin{array}{c}0.761 * * * \\
(3.31)\end{array}$ & $\begin{array}{l}0.247 \\
(1.50)\end{array}$ & & $\begin{array}{c}0.084 * * * \\
(2.91)\end{array}$ & $\begin{array}{l}0.107 \\
(1.55)\end{array}$ \\
\hline$\alpha_{5} \delta_{t}$ & & $\begin{array}{l}0.050 \\
(0.23)\end{array}$ & $\begin{array}{c}-0.239 * * * \\
(2.88)\end{array}$ & & $\begin{array}{l}-0.001 \\
(0.09)\end{array}$ & $\begin{array}{l}-0.018 \\
(0.66)\end{array}$ \\
\hline$\alpha_{6} \delta_{t}^{2}$ & & $\begin{array}{l}-0.015 \\
(1.12)\end{array}$ & $\begin{array}{c}0.005^{* * *} \\
(2.86)\end{array}$ & & $\begin{array}{l}0.000 \\
(1.46)\end{array}$ & $\begin{array}{l}0.000 \\
(0.79)\end{array}$ \\
\hline$n$ & & $\begin{array}{l}0.012 \\
(1.11)\end{array}$ & $\begin{array}{c}0.040 * * * \\
(2.78)\end{array}$ & & $\begin{array}{l}0.242 \\
(1.37)\end{array}$ & $\begin{array}{l}0.041 \\
(1.28)\end{array}$ \\
\hline$g$ & $\begin{array}{c}0.013 * * * \\
(19.42)\end{array}$ & $\begin{array}{c}0.032 * * * \\
(3.08)\end{array}$ & $\begin{array}{c}0.050^{* * * *} \\
(3.60)\end{array}$ & $\begin{array}{c}0.011^{* * * *} \\
(8.88)\end{array}$ & $\begin{array}{c}0.021 * * * \\
(3.65)\end{array}$ & $\begin{array}{c}0.018^{* *} \\
(1.96) \\
\end{array}$ \\
\hline Observations & 7622 & 7622 & 7622 & 1284 & 1284 & 1284 \\
\hline R-squared & 0.52 & 0.46 & 0.52 & 0.50 & 0.48 & 0.52 \\
\hline
\end{tabular}

Sources: ICA Senegal, FACS Morocco.

All regressions are estimated using non-linear least squares, models (A) and (C) including firm factors. Absolute value of $\mathrm{t}$ statistics are in parentheses, significance levels being respectively equal to $1 \%(* * *), 5 \%(* *)$ and $10 \%(*)$. All regressions also include a set of dummies for occupation. 
Figure 1. Rates of return to tenure - Mincer earnings regressions A. Morocco
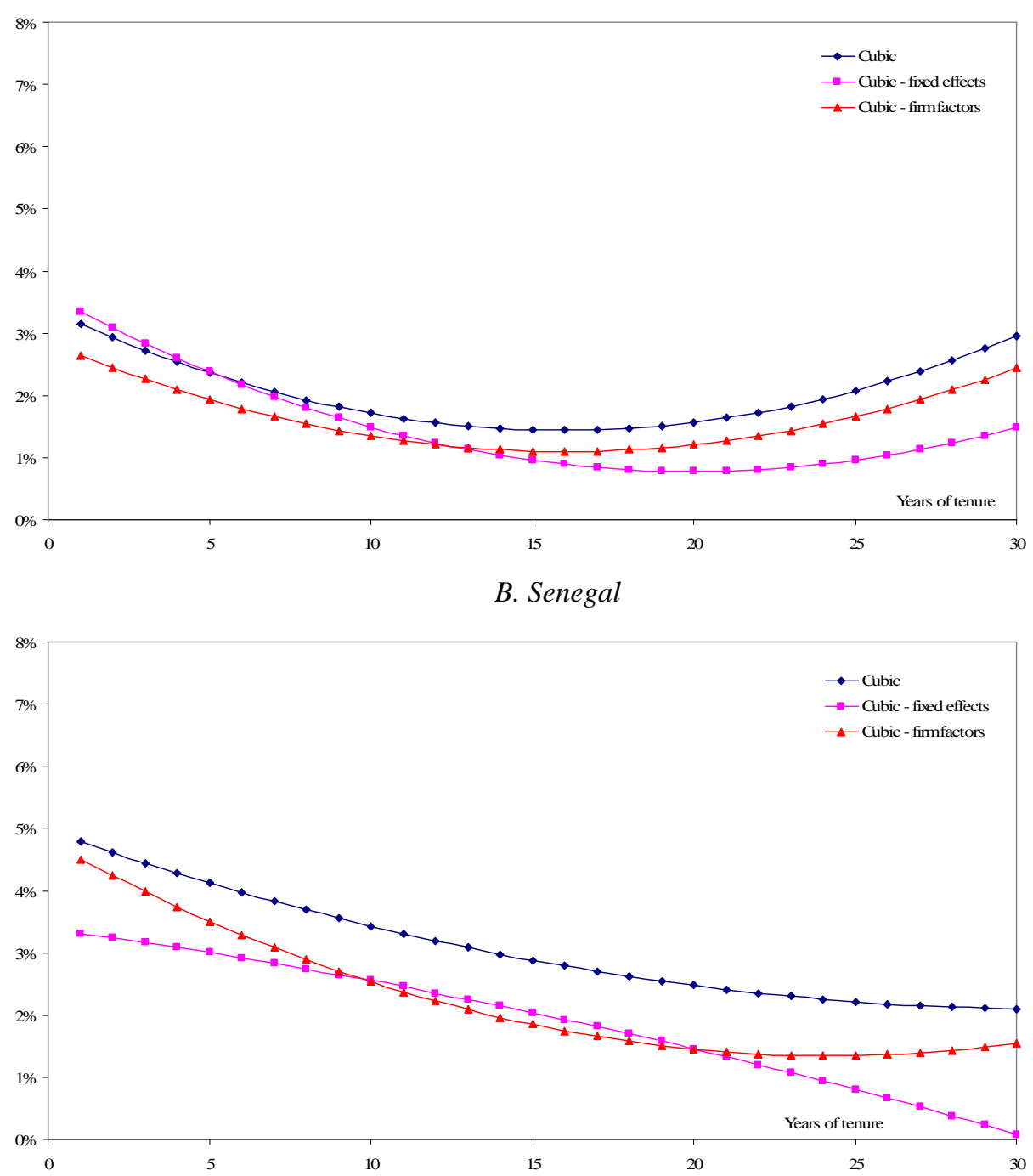

Sources: ICA Senegal, FACS Morocco. 
Figure 2. Time needed to accumulate the firm knowledge

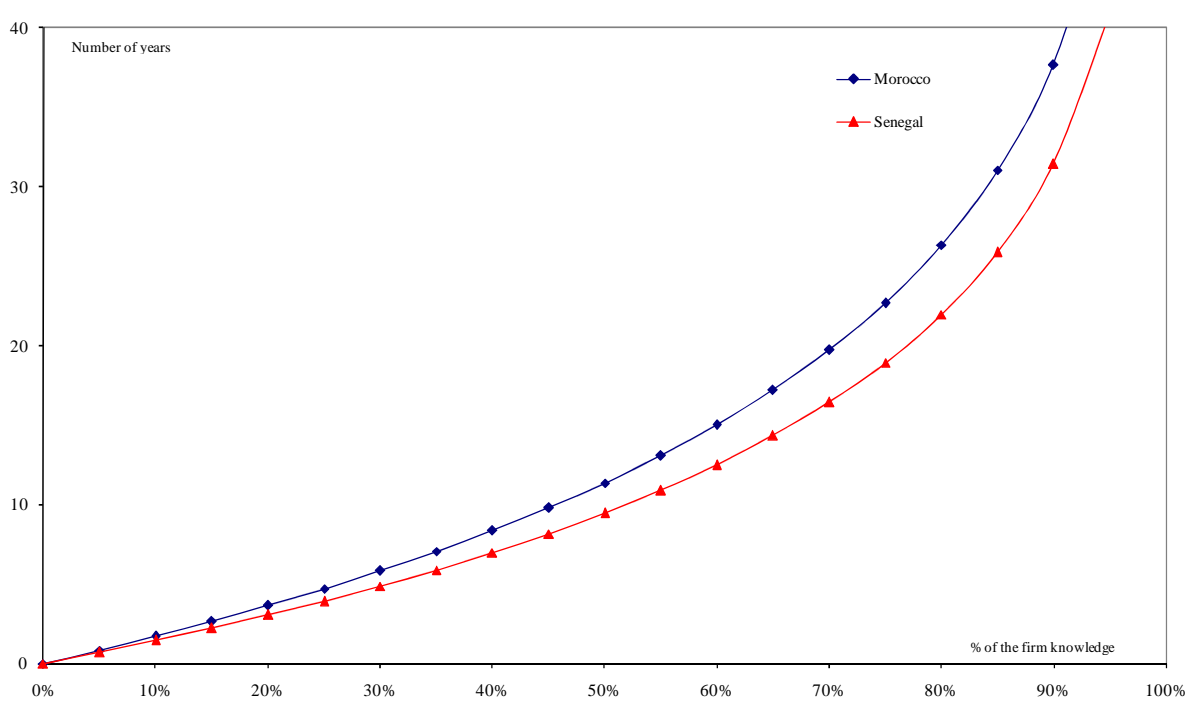

Sources: ICA Senegal, FACS Morocco.

Figure 3. Rates of return of tenure - learning-by-watching models A. Morocco

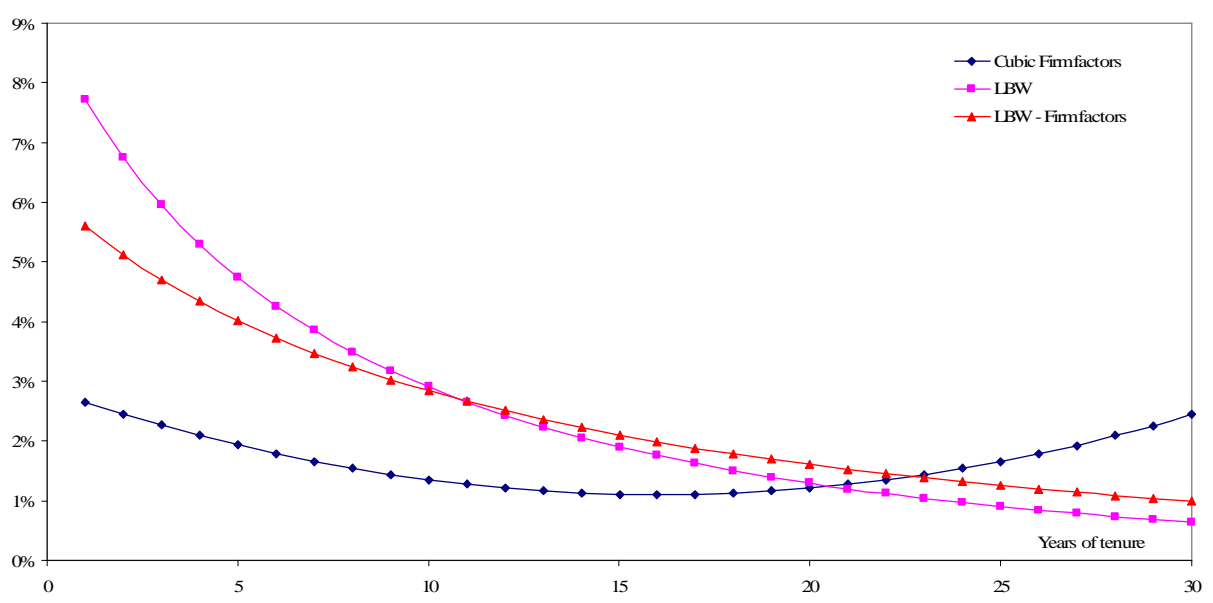

B. Senegal

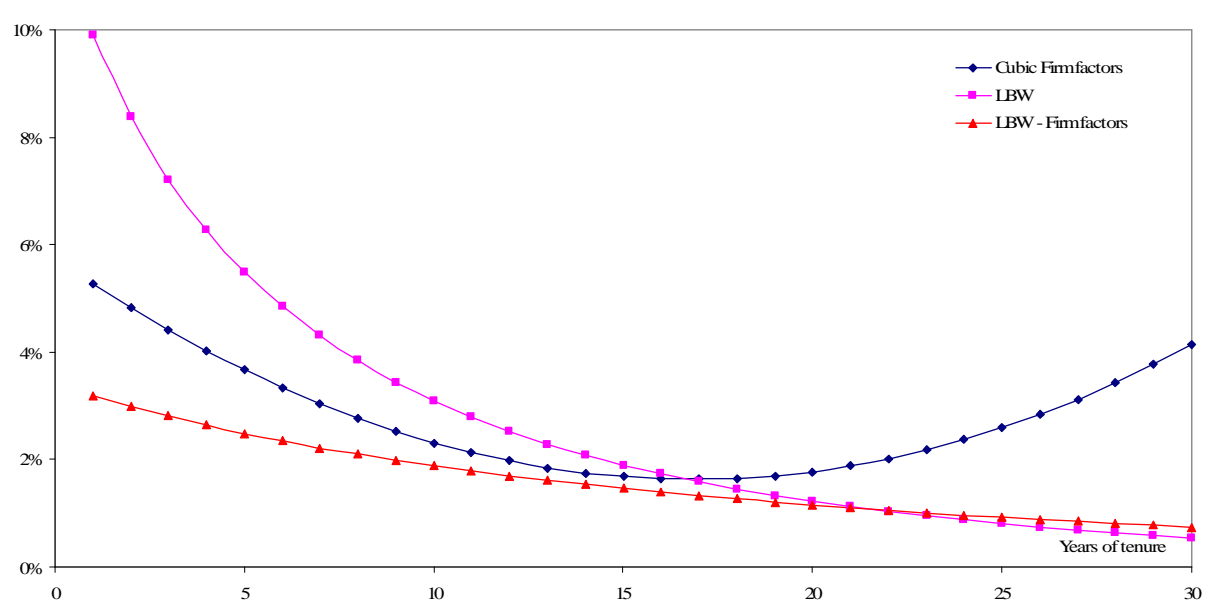

Sources: ICA Senegal, FACS Morocco. 